
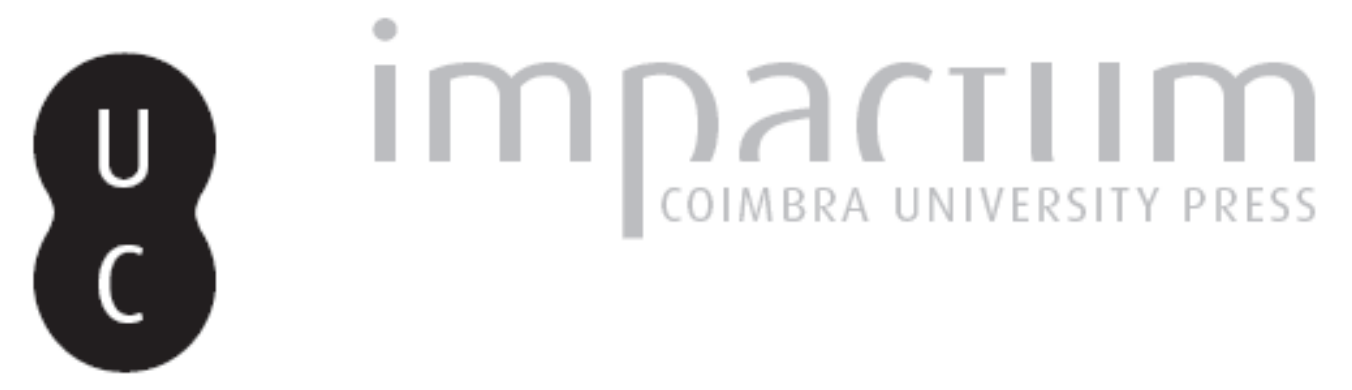

\title{
O povoado pré-histórico do Ramalhão (Penamacor): resultados das escavações de 1988 e 1989
}

\author{
Autor(es): Vilaça, Raquel
}

Publicado por: Imprensa da Universidade de Coimbra

URL persistente:

URI:http://hdl.handle.net/10316.2/45565

DOI:

DOI:https://dx.doi.org/10.14195/1647-8657_28_1

Accessed : $\quad$ 26-Apr-2023 12:29:49

A navegação consulta e descarregamento dos títulos inseridos nas Bibliotecas Digitais UC Digitalis, UC Pombalina e UC Impactum, pressupõem a aceitação plena e sem reservas dos Termos e Condições de Uso destas Bibliotecas Digitais, disponíveis em https://digitalis.uc.pt/pt-pt/termos.

Conforme exposto nos referidos Termos e Condições de Uso, o descarregamento de títulos de acesso restrito requer uma licença válida de autorização devendo o utilizador aceder ao(s) documento(s) a partir de um endereço de IP da instituição detentora da supramencionada licença.

Ao utilizador é apenas permitido o descarregamento para uso pessoal, pelo que o emprego do(s) título(s) descarregado(s) para outro fim, designadamente comercial, carece de autorização do respetivo autor ou editor da obra.

Na medida em que todas as obras da UC Digitalis se encontram protegidas pelo Código do Direito de Autor e Direitos Conexos e demais legislação aplicável, toda a cópia, parcial ou total, deste documento, nos casos em que é legalmente admitida, deverá conter ou fazer-se acompanhar por este aviso.

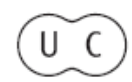


FACULDADE DE LETRAS

INSTITUTO DE ARQUEOLOGIA

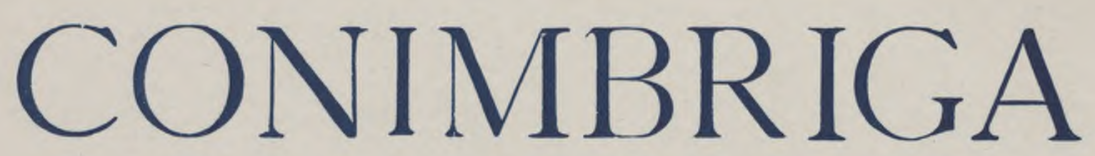

VOLUME XXVIII

UNIVERSIDADE DE COIMBRA

1989 


\section{RAQUel Vilaça}

Assistente do Instituto de Arqueologia da Faculdade de Letras de Coimbra. Bolseira do INIC.

O POVOADO PRÉ-HISTÓRICO DO RAMALHÃO (PENAMACOR) : RESULTADOS DAS ESCAVAÇÕES DE 1988 e 1989.

«Conimbriga», XXVIII, 1989, p. 5-32.

Resumo: Publica-se o relatório final das escavações realizadas no povoado do Ramalhão (Penamacor) durante os anos de 1988 e 1989. A análise conjunta das condições de jazida encontradas e do material exumado permitiu definir uma única fase de ocupação, atribuível ao Neolítico Final/Calcolítico, praticamente desconhecidos nesta região da «Beira Raiana».

SUMMARY : We present the final excavation report of the settlement of Ramalhão (Penamacor) covering the years 1988 and 1989.

The analyses of the stratigraphy, combined with that of the material exhumed, allowed us to conclude that this settlement had one phase of occupation only, attributable to the late Neolithic/Calcolithic era. These periods were hitherto unknown in the region of «Beira Raiana». 
(Página deixada propositadamente em branco) 


\section{O POVOADO PRÉ-HISTÓRICO DO RAMALHÃO (PENAMACOR) RESULTADOS DAS ESCAVAÇÕES DE 1988-1989}

\section{Introdução}

A estação arqueológica do Ramalhão, também conhecida por «Serra Pedreira», foi identificada em finais da década de 70, por Manuel Leitão. Na notícia que dela publicou (LeITão, 1982, 17) atribui os materiais cerâmicos, recolhidos em prospecção, ao Bronze/Ferro, identificando bordos de cerâmica carenada, que inclui nas formas M12 e 15 e TU do conjunto de Alpiarça (Marques, 1972, Est. II).

Em 1979, Joaquim Baptista estuda materiais cerâmicos da Serra Pedreira, fornecidos por Manuel Leitão, e confirma aquela cronologia (BAPTISTA, 1982, 77-78).

Estas duas notícias revelaram-se-nos da maior importância, na medida em que vinham de encontro ao projecto de investigação que visa o estudo do povoamento da Beira Interior durante a Idade do Bronze, sobre o qual trabalhamos. Contactámos, assim, ambos os autores, informando-os da existência do nosso projecto e do nosso interesse em analisar os materiais em causa, dado que nenhum desenho ou fotografia tinha sido publicado $\left({ }^{1}\right)$.

(1) Tais materiais nunca foram por nós observados, uma vez que ambos os autores dizem desconhecer o seu actual paradeiro; os nossos esforços para os localizar nos museus de Penamacor e Castelo Branco foram igualmente inúteis. 
Depois de termos visitado a estação em Setembro de 1987, programámos uma campanha de escavações com o objectivo de tentar correlacionar os materiais noticiados com outros contextualizados e assim reunir dados que ajudassem a esboçar o tipo de ocupação humana existente no Ramalhão.

Este trabalho dá notícia dos resultados obtidos nas duas

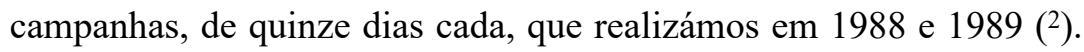
A análise dos dados e o seu estudo comparativo afasta-se bastante dos resultados a que chegaram aqueles dois autores, constituindo uma surpresa, mas trazendo também novos elementos sobre a problemática das origens do Calcolitico, bastante mal conhecido, nesta região interior. Assim, se justifica a divulgação nesta notícia dos dados obtidos. Por outro lado e admitindo que é correcta a interpretação daqueles dois colegas, a importância do Ramalhão como estação arqueológica vê-se acrescida, por abarcar, segundo este raciocínio, pelo menos duas fases de ocupação bem distintas.

\section{Localização geográfica}

O monte do Ramalhão insere-se num conjunto de elevações graníticas situadas a sudeste daquela onde se encontra a vila de Penamacor. Aquelas elevações são também designadas por «Serra Pedreira» e somente a de maior altitude absoluta, com 542 metros, é igualmente denominada por Ramalhão.

(2) Além de três trabalhadores camarários, as equipas foram constituídas pelos seguintes alunos ou recém-licenciados da Faculdade de Letras da Universidade de Coimbra: Dr. Pedro Sobral, Dr. ${ }^{a}$ Alice Semedo, Ana Cristina Farinha, Helena Goulão, Maria Miguel Lucas, Ana Caessa, Paula Correia, Júlia Pinção, Olímpio Ferreira, Filomena Gaspar, Inés Byrne, Isabel Alves Ferreira, José Alberto Moutinho e Mário Silva.

Os trabalhos realizaram-se com subsídios do Instituto Português do Património Cultural e da Câmara Municipal de Penamacor, que garantiu ainda o alojamento e transporte diário. Contámos, também, com apoio técnico do Serviço Regional de Aiqueologia da Zona Centro. Agradecemos a todas estas entidades a sua colaboração. 
O Ramalhão ocupa, por isso, uma posição bem destacada na paisagem, que lhe advém não tanto da sua altitude, mas por constituir um relevo isolado. O desnível entre o ponto mais alto, que designámos por sector $\mathrm{V}$, e o sopé, é da ordem dos 65 metros.

Este sítio pertence à freguesia e concelho de Penamacor, do distrito de Castelo Branco. As suas coordenadas geográficas, tomando como referência o seu ponto médio, são as seguintes (segundo a Carta dos Serviços Cartográficos do Exército, folha 248, na escala 1:25.000) :

$$
\begin{aligned}
& \text { Longitude }-7^{\circ} 09^{\prime} 06^{\prime \prime} \mathrm{W} \text { Gr. } \\
& \text { Latitude }-40^{\circ} 09^{\prime} 03^{\prime} \mathrm{N}
\end{aligned}
$$

A paisagem envolvente é preenchida, a norte, pelos contrafortes xistosos da Serra da Malcata, pertencente à «Superfície da Meseta», enquanto que nos outros sentidos domina a planície, de potencialidade agrícola importante na região, salpicada de quando em quando por modestas elevações que se inserem na «Superfície de Castelo Branco». O Ramalhão situa-se, assim, no limite orográfico que, segundo Orlando Ribeiro, divide o Norte e o Sul de Portugal (Riberro et olii, 1987, 135), precisamente na altura em que se anuncia o Alentejo. Enquadra-se, pois, num ambiente de cariz mediterrânico, com carvalho negral, sobreiro, azinheira e esteva.

A sua configuração é grosseiramente oblonga; os lados sul e poente apresentam vertentes íngremes, enquanto que a norte e oriente o pendor é mais suave, até atingir o vale do ribeiro do Mourisco. O sopé encontra-se drenado com diversas linhas de água que correm para aquele ribeiro ou que lhe são independentes, como as ribeiras das Taliscas e da Penela, respectivamente a sudeste e a oeste, continuando pelo rio Torto, que alimenta o Ponsul, afluente do Tejo.

O substracto rochoso é de constituição granítica $\left({ }^{3}\right)$, aflorando à superfície numerosos blocos graníticos que envolvem parcial-

(3) Carta Geológica de Portugal, esc. 1:500.000, 1972, da Direcção-Geral de Minas e Serviços Geológicos. Estranhamente, Joaquim Baptista afirma que a rocha predominante é o xisto (BAPTISTA, 1982, 76). 
mente as plataformas existentes na serra. Espessura do solo variável, mas sempre pouco significativa, revelando um intenso processo de erosão. A presença de socalcos artificiais e de restos de antigos muros denunciam a prática de uma agricultura, hoje abandonada, que deu lugar ao crescimento espontâneo da giesta branca e negra, rosmaninho, fetos e estevas; encontram-se também frondosos carvalhos, sobreiros e oliveiras.

O acesso pode fazer-se, com automóvel, desde Penamacor até ao «campo da bola», junto à estrada que segue para a fronteira, e, depois, tomando o caminho que circunda o monte pelo lado norte; para subir até à estação, é necessário fazer o percurso a pé. No sopé, a nascente, conservam-se troços de uma antiga via, considerada romana por alguns $\left({ }^{4}\right)$.

\section{Sondagens e estratigrafía}

As duas campanhas realizadas pautaram-se pela abertura de valas de sondagem, localizadas em diferentes plataformas com posições topográficas distintas. À superfície não se reconheciam quaisquer estruturas e o material, bastante raro, não apresentava qualquer concentração mais sugestiva. Sem outros dados que nos pudessem ajudar a optar por esta ou aquela plataforma, privilegiámos a área central e oriental da serra, onde a vegetação era menos densa, para a realização das sondagens.

Estas visavam a detecção de locais que oferecessem boas condições de jazida, passíveis de fornecer informações precisas em termos cronológico-culturais, a fim de serem, posteriormente, escavados em área. Neste sentido, foram seleccionadas onze plataformas que passaram a ser designadas por sectores (de I a XI).

Todas as sondagens foram sujeitas à mesma metodologia, integradas num sistema de quadrícula ( 1 x $1 \mathrm{~m})$, com uma orientação segundo a direcção N/S (s); todas as cotas foram estabelecidas

(4) Esta via é conhecida por «calçada das Eirinhas» (LANDEIRo, 1961, 150).

${ }^{5}$ ) Exceptuam-se as sondagens realizadas no sector VIII, cuja orientação se fez no sentido NW/SE, em função das curvas de nível da plataforma a que corresponde. 
em função dum ponto convencional zero, de valor superior a todos os outros, de forma que as cotas são sempre negativas. A totalidade da área intervencionada, reunindo as sondagens de todos os sectores, perfaz cerca de $170 \mathrm{~m}^{2}$.

$O$ interesse das sondagens efectuadas varia de sector para sector, tendo-se verificado casos em que a informação foi quase nula, dado que a rocha de base surgiu a escassos centímetros de profundidade. Com excepção dos sectores VII, IX, X e XI, onde se verificou esta situação, e dos sectores I e VIII, cuja estratigrafía descrevemos adiante, os restantes sectores forneceram idênticas características a nível estratigráfico : uma camada superficial, humosa e pouco compacta, com material arqueológico por vezes associado a material recente; a segunda camada, nem sempre explícita, desenvolvia-se a partir da rocha-mãe, com textura arenosa e tonalidade mais clara, também com material arqueológico.

As características das camadas e as condições em que surgiu o material exumado, nomeadamente, cerâmico (muito fragmentado, de superfícies corroídas, fracturas boleadas), denunciam um processo de escorregamento e transporte, associado a agricultura, levando-nos a considerar que as plataformas correspondentes àqueles sectores serão periféricas ao núcleo onde se implantou o grupo humano pré-histórico que habitou a serra. Se é certo que esta hipótese poderá ser admissível, não deverá, porém, excluir uma outra que não contemplará um estabelecimento nuclearizado, mas uma ocupação mais dispersa e de natureza bastante precária.

$\mathrm{O}$ corte que realizámos na pequena plataforma exposta e virada a sul, designada por sector I (Est. Ill), forneceu dados estratigráficos que permitiram definir quatro camadas. As camadas 1 e 2, apenas diferenciadas pela tonalidade mais escura da segunda, correspondem a acumulações de terra e materiais relativamente recentes. A estas camadas correspondem os fragmentos cerâmicos com superfícies corroídas. As camadas 3 e 4, muito mais compactas, apenas forneceram material pré-histórico; a camada 3, de tonalidade muito escura, poderá eventualmente testemunhar restos de um nível de ocupação, apesar de não terem sido detectadas estruturas ou sequer associações significativas de material; a 
camada 4 é correlacionável com a camada 2 dos sectores já descritos.

Especial destaque merece o sector VIII, definido por uma ampla plataforma de pendor assinalável no sentido NW/SE. Situa-se na parte ocidental da serra, entre o sector XI, que lhe fica a norte e a uma cota inferior, e os sectores III e IV, a sul e a sudeste, respectivamente; a poente, encontra-se uma enorme massa de afloramentos graníticos, junto ao rebordo ocidental, que separa a plataforma da vertente.

Este foi o único sector escavado em área, cobrindo cerca de $79 \mathrm{~m}^{2 * * *}$ (Est. IV). Inicialmente foram abertas duas valas de sondagem, posteriormente ampliadas pela importância dos elementos recolhidos. A zona mais importante corresponde a uma pequena área que forneceu material in situ, relacionado com uma fossa, permitindo definir um nível de ocupação (Est. VI). Nesta área de maior concentração de material, foram recolhidos alguns pedaços de uma substância argilosa (particularmente no quadrado D2, junto à mó), aparentemente queimados, que poderão testemunhar vestígios de estruturas de combustão muitíssimo destruídas $\left(^{6}\right)$.

A fossa que referimos, cuja função desconhecemos, foi detectada apenas na base da camada 3; apresenta uma configuração sensivelmente circular, com 68/73 cm de diâmetro e a profundidade máxima de $28 \mathrm{~cm}$. No seu interior foram recolhidos três fragmentos de cerâmica (bojo) e alguns carvões dispersos, de pequena dimensão. Foram ainda definidas duas manchas escuras (Est. IV) de espessura diminuta, cujo significado não foi totalmente compreendido.

Nesta mesma área que acabámos de descrever, atingiu-se a profundidade absoluta de 33 (mínima) e $72 \mathrm{~cm}$ (máxima). Foram analisados dois cortes que forneceram a seguinte estratigrafía (Est. V) : a camada 1, de tom acastanhado, a que corresponde o solo

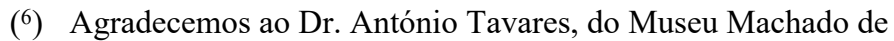
Castro (Coimbra), a elaboração de uma lâmina delgada desta substância argilosa. A sua análise, segundo informação daquele investigador, revelou tratar-se de uma argila muito fina submetida a fogo, composta por grãos de quartzo e algum feldspato, pouco abundantes, de pequeno calibre e muito angulosos; encontrava-se impregnada de matérias carbonosas. 
arável, apresentava uma textura bastante solta e com muitas raízes; a camada 2 , de tonalidade igualmente castanha, mas mais escura, mais compacta e com material arqueológico mais abundante; apenas foi detectada em algumas zonas, confundindo-se noutras com a camada 1 ; deverá corresponder ao nível de abandono desta área do habitat; a camada 3, de tom castanho-amarelado, tinha uma textura fina e granulosa e desenvolvia-se a partir do solo de base; o material arqueológico era bastante abundante e parte encontrava-se in situ (topo da camada 3).

Os elementos fornecidos pelas sondagens realizadas levam-nos a considerar a existência de um habitat, porventura de natureza precária, cujo núcleo principal ou mais bem conservado não foi ainda identificado. Com efeito, se exceptuarmos a área do sector VIII, qualquer um dos outros não forneceu elementos concludentes acerca do tipo de organização do habitat, nem se registaram associações sugestivas ao nível do espólio exumado. Todos eles parecem corresponder a áreas periféricas, onde ficou retido, nas respectivas plataformas, diverso material, que acompanhou e sofreu um processo gradual de erosão.

Pelo contrário, no sector VIII foi possível identificar um nível de ocupação, com material in situ, materializado na camada 3 , e correlacionável com uma estrutura aberta no saibro de base. Apesar de parcos, estes são os dados disponíveis, que nos permitem esboçar a caracterização deste possível povoado, um dos mais antigos testemunhos de sedentarização na zona. A articulação da estratigrafía definida e dos materiais exumados indicam-nos a existência de uma única fase cronológico-cultural.

\section{Espólio}

Com excepção de duas mós (dormentes) fracturadas, achadas à superfície na área do sector I, todo o material estudado é proveniente das sondagens realizadas $\left({ }^{7}\right)$.

(7) Como referimos, nunca nos foi possível analisar o material exumado por Manuel Leitão e por Joaquim Baptista.

As duas mós encontradas à superfície foram depositadas no Museu Municipal de Penamacor, instituição que receberá o material das nossas 
0 estudo descritivo e analítico do material foi feito separadamente por sectores e, em cada um deles, por camadas. Apresentam-se os resultados globais desse estudo, primeiro dos líticos e, depois, do material cerâmico. Não foi encontrada qualquer peça metálica.

\section{1. $\operatorname{Liticos}\left({ }^{8}\right)$}

A primeira verificação referente à indústria litica desta estação reside na sua raridade, nomeadamente no que respeita à pedra lascada. Analisando o quadro que reúne este tipo de material (Quadro I), verifica-se a ausência de peças típicas, comuns a povoados de natureza idêntica ou próxima do nosso, e a quase inexistência de material retocado. Resume-se a lascas e lâminas com vestígios de talhe mal definidos e muito simples. A matéria-prima utilizada — sílex, calcedonia e quartzito - não é desconhecida na zona $\left({ }^{9}\right)$, o que leva a pensar numa obtenção acessível por parte dos habitantes do Ramalhão.

A pedra polida está mais bem representada, quer em termos numéricos, quer na qualidade das peças.

Podemos definir dois grandes grupos: os elementos de moinho, ligados à trituração de cereais, bolota, ou outros vegetais, e os machados/enxós, a que se ligam normalmente os trabalhos agrícolas ou em madeira.

As características deste último grupo encontram-se expressas no Quadro II. De notar que as peças n. ${ }^{\circ} 88-4$ e n. ${ }^{\circ} 88-1$ apresentam vestígios de uso no gume. A peça $n .^{\circ} 89-1$ é proveniente da área do

escavações após a autorização devida; encontra-se provisoriamente na sede do Serviço Regional de Arqueologia da Zona Centro.

$\mathrm{O}$ desenho do material litico e cerâmico é da autoria do Dr. José Luís Madeira, com excepção das peças de pedra polida n. ${ }^{\circ}$ 88-4 e n. ${ }^{\circ} 89-1$, desenhadas por Ana Cristina Farinha.

$\left.{ }^{8}\right)$ A identificação da matéria-prima das peças líticas foi feita pelo Dr. Huet Bacelar, do Instituto de Antropologia da Faculdade de Ciências da Universidade do Porto, e pelo Dr. José Pinto, do Laboratório de Mineralogia da Faculdade de Ciências da Universidade de Coimbra. Agradecemos a ambos a sua colaboração.

(9) A Carta Geológica de Portugal, na escala 1:50.000, correspondente ao Sabugal (folha 21-A) refere-se aos quartzitos e aos quartzos calcedónicos.

Conimbriga, 28 (1989), 5-32 
sector Vili com maior concentração de material, tendo-se encontrado in situ. A matéria-prima utilizada foi sempre $\mathrm{o}$ anfibolito, o que é, aliás, frequente em utensílios deste tipo. Quer os machados quer as enxós são elementos de cronologia pouco segura e com uma dispersão geográfica muito vasta, limitando, por isso, as ilações que desejaríamos obter com o seu estudo.

Os elementos de mó recolhidos (Quadro III) são todos do mesmo tipo — de vaivém-, comportando duas categorias: os elementos fixos ou dormentes, quase sempre de maiores dimensões, e os elementos moventes ou rebolos. Em cada uma das categorias as dimensões são variadas; merece destaque a dormente n. ${ }^{\circ} 88-5$, completa, com dimensões bastante mais reduzidas em comparação com as restantes, podendo corresponder à trituração de produtos de diferente natureza, nomeadamente de origem mineral.

Todas elas, dormentes e moventes, são de granito, com excepção da movente n. ${ }^{\circ} 89-5$, que é em aplito granítico. Ambos os materiais se encontram na própria serra do Ramalhão. Predominam as secções plano-convexas e sub-rectangulares.

De assinalar, ainda, o achado conjunto da movente $n .^{\circ} 88-2$ e da dormente $n .^{\circ} 88-3$, bem como da dormente $n .^{\circ} 88-5$ e de um seixo natural, classificado como triturador/percutor, a que nos referimos adiante. Ambas as associações são significativas e contribuíram para a correcta interpretação estratigráfica em que se inseriam. A multiplicidade de funções dum mesmo utensílio é-nos proporcionada pela pequena movente (Est. XII-n. ${ }^{\circ} 2$ ), totalmente polida, que apresenta numa das faces, na sua parte central, sinais evidentes de ter sido utilizada igualmente como percutor.

Além das peças que acabámos de analisar, foram também exumados alguns seixos naturais utilizados como instrumentos. Classificámos como percutor um seixo em quartzito, proveniente do sector III, de forma oval e secção circular, apresentando, num dos extremos e na parte central de uma das faces, vestígios de ter tido aquela função (Est. XVII-1). Idêntica classificação foi atribuída um outro seixo natural, em aplito granítico, de forma e secção elípticas, encontrado junto à dormente $n .{ }^{\circ} 88-5$; é provável que tivesse sido igualmente utilizado como triturador ou movente, dado o polimento das faces; o seu achado, relacionado com a dormente, valoriza esta hipótese. 
Um fragmento de grauvaque alterado, bastante abundante na serra da Malcata, recoberto por óxidos de ferro, encontrado no sector III, apresenta vários riscos e sulcos intencionais numa das faces; classificámo-lo como possível alisador (Est. XX-2).

Para concluir o estudo do material litico, resta-nos referir a conta de colar encontrada no sector Vili. É em xisto, discoidal, achatada e com perfuração central (CAMPs, 1981-289-290). A dispersão geográfica, a natureza das jazidas em que aparece e a sua conotação cronológico-cultural são bastante amplas.

\subsection{Cerâmica}

O elevado grau de fragmentação da cerâmica e o boleamento das suas fracturas limitou bastante a reconstituição dos vasos, impossibilitando, na maior parte dos casos, o seu real e completo conhecimento morfológico. A análise técnica das pastas baseou-se na observação macroscópica, tendo-se recorrido, num ou noutro caso, à utilização de uma lupa de aumento. No seu estudo tiveram-se em atenção os seguintes aspectos: tipo de fabrico (manual ou ao torno), identificação do fragmento (bordo, bojo, fundo) $\left({ }^{10}\right)$, tipo de pasta (friável, homogénea, compacta), tipo de superfície (alisada, polida, corroída), espessura das paredes, diâmetros do bordo e fundo (nos casos em que tal foi possível) e decoração. Se bem que a cor das paredes e do núcleo dos fragmentos tivesse igualmente merecido a nossa atenção, não lhe foi atribuída uma deferência sistemática por considerarmos o seu significado de importância secundária. Apresentam-se aqui os resultados de conjunto.

Ao nível técnico, regista-se o predomínio das pastas grosseiras ou semi-grosseiras, compactas e micáceas ${ }^{(11)}$. Predominam as

${ }^{(10)}$ Admitimos a possibilidade de alguns fragmentos classificados como bojos corresponderem efectivamente a fundos arredondados; o seu estado de fragmentação não nos permite ir mais longe.

(u) $\mathrm{Na}$ análise do material cerâmico, baseámo-nos no estudo de H. Balfet (BALFET et alii, 1983), de que, porém, nos afastámos num ou noutro pormenor. Por exemplo, a análise macroscópica que efectuámos não nos permitiu adoptar a escala granulométrica proposta por aquela ceramóloga, aliás adoptada de Shepard. Apenas distinguimos e. n. p. de grande calibre $>1 \mathrm{~mm}$, médio 
superfícies alisadas, sempre com percentagens acima dos $75 \%$; as polidas têm algum significado apenas nos sectores I (camadas 3 e 4), IV (camada 2) e VIII (camada 3); as corroídas, comuns a todos os sectores, testemunham uma acção de transporte e escorregamento. De notar a ausência de superfícies brunidas ou fortemente polidas, tão comuns às formas do grupo de Alpiarça identificadas por Manuel Leitão e Joaquim Baptista. No que respeita à cor, têm maior expressão numérica os recipientes com tonalidades que vão do acastanhado ao alaranjado, sendo bastante frequentes os que reúnem diversos tons, sugerindo uma cozedura irregular. Em relação à espessura das paredes, regista-se o predomínio das paredes medianamente espessas.

A nota dominante desta análise reside numa assinalável uniformidade técnica, que contrasta com a diversidade morfológica, como demonstraremos a seguir.

Antes de passarmos à descrição dos tipos morfológicos definidos nos diversos sectores, é conveniente afirmar a total ausência de bordos denteados e carenas correspondentes às formas da cerâmica de Alpiarça, já referidas, elementos que tinham permitido atribuir esta estação ao Bronze Final (LeItão, 1982; BAptista, 1982); assinale-se, também, a inexistência de asas.

Foram os sectores escavados em maior extensão - IV e VIII - os que forneceram maior variedade tipológica ao nível cerâmico.

$\mathrm{Na}$ análise dos bordos, teve-se em conta o tipo de lábio (convexos, planos e sub-rectilíneos) e a sua orientação (extrovertido, vertical, inclinado para o interior). Predominam os bordos convexos, seguidos dos planos; o número de bordos inclinados para o interior é superior aos extrovertidos, factor que intervirá na definição dos tipos a que chegámos.

calibre: 0,5 a $1 \mathrm{~mm}$ e pequeno calibre $<0,5 \mathrm{~mm}$. No que respeita à natureza dos e. n. p., predominam os grãos de quartzo e as partículas de mica; para o conjunto cerâmico estudado, entendemos por pastas micáceas as que contêm partículas de mica em proporções idênticas às dos grãos de quartzo ; a dimensão que algumas atingem, mais de $1 \mathrm{~mm}$, e o contraste do seu brilho com o fundo mate justificam esta classificação.

Conimbriga, 28 (1989), 5-32 
Relativamente aos fundos, apenas foi possível a identificação de cinco : 4 planos e 1 convexo.

O estado lastimável em que se encontrava a cerâmica constituiu um grande obstáculo à determinação dos tipos morfológicos. Estes basearam-se na análise dos bordos e fundos, muitas vezes sem hipótese de determinação dos diâmetros, já que não foi possível reconstituir integralmente qualquer recipiente.

O tipo 1 corresponde aos recipientes que apresentam corpo e fundo esférico; a boca é fechada. Foram estabelecidos dois subtipos, em função da presença ou ausência (a maioria) de um pequeno estrangulamento no bordo. Compreende formas lisas e decoradas, neste caso, com mamilos de forma ovoide ou alongados e dispostos verticalmente; em ambas as variantes surgem sob o bordo. Apresenta uma posição expressiva em quase todos os sectores (I, III, IV, V e VIII), correspondendo a $31,37 \%$ do total dos fragmentos estudados.

O tipo 2 compreende recipientes cuja forma geral se baseia na meia-esfera, sendo portanto desprovidos de colo e carena; engloba uma diversidade de lábios e bordos assinalável, que se associam a formas lisas e decoradas, estando, neste caso, presente a decoração plástica e a decoração incisa associada ao puncionamento. A maior ou menor abertura dos recipientes deste tipo, que alguns autores denominam «taças em calote», permitiu a definição de sub-tipos. A sua representatividade nos diversos sectores é igualmente significativa (I 04, III, IV V e VIII 03), com 42,48 \%.

No tipo 3 foram englobadas as «taças carenadas», correspondendo a formas lisas, abertas e pouco profundas; o fundo é em calote. Apresenta uma baixa percentagem - 2,6\% - correspondente a 4 exemplares. A sua distribuição pelos sectores é circunscrita (sectores I 04, Ile IV).

No tipo 4 incluímos os recipientes ligeiramente fechados, com o bordo inclinado para o interior e uma aresta mais ou menos angulosa. Foram estabelecidos dois sub-tipos. Está representado por 4 exemplares, todos do sector VIII 03, que equivalem a 2,6 \%.

O tipo 5, a que corresponde um único exemplar do sector VIII 03, apresenta uma carena muito baixa, o fundo convexo e as paredes mais ou menos verticais; desconhece-se o tipo de bordo. Representa $0,6 \%$ do total. 
O tipo 6 reúne os recipientes de corpo esférico ou ovoide, boca fechada e bordo inclinado para o interior; alguns bordos apresentam-se com um ligeiro espessamento externo. Corresponde sempre a formas lisas com uma representatividade a nivel sectorial bastante diversa (sectores I 03 e 04, III, IV, V e VIII 03). Soma 8,4 \%.

No tipo 7 incluimos os fundos planos, escassamente representados (4 exemplares) com 2,6\% no conjunto total dos fragmentos analisados. Corresponderão a vasos de corpo ovoide ou tronco-cónico (sub-tipos A e B).

O tipo 8 integra recipientes de boca fechada, corpo provavelmente ovoide e fundo plano; apresentam ainda o colo estrangulado. Só está representado nos sectores I 04 e IV, com 7,18 \%.

Estabelecemos um último tipo, tipo 9, correspondente a um único exemplar classificado como «colher», encontrado no sector VIII 03. Perfaz $0,6 \%$ do total cerâmico estudado.

Antes de passarmos à análise particular de cada tipo e ao seu estudo comparativo, é importante referir que nenhum deles é exclusivo do Ramalhão ou da região em que este povoado se integra. É igualmente importante insistir na completa ausência de formas ou tipos atribuíveis ao Bronze Final (Leitão, 1982, e BAptista, 1982). Pelo contrário, os tipos identificados, ou a sua maioria, encontram-se em contextos habitacionais e sepulcrais com uma expressão geográfica e cronológica bastante ampla. Tentaremos estabelecer paralelos formais com contextos das regiões mais próximas - Beira Alta e Alto Alentejo, Meseta e Extremadura espanhola - com o Norte e o Sul de Portugal.

O tipo 1 corresponde a uma forma primária de ascendência neolítica e, por isso, sem grande significado cronológico-cultural. No Ramalhão aparece em segundo lugar, logo depois das taças em calote ou semi-esféricas. É comum a povoados e sepulcros. Apesar da distribuição genérica deste tipo, é possível, em função dos dados disponíveis, referir algumas particularidades regionais. Por exemplo, encontramo-lo em diversos povoados calcolíticos da Meseta ocidental, como os de Peña del Aguila (Ávila) e Teso del Moral (Zamora), mas em baixas percentagens (Lopez Plaza, 1979, 73), contrariamente ao que sucede no Ramalhão. Tem também representação significativa em vários povoados calcolíticos do Norte de Portugal, nomeadamente na região de Chaves/Vila Pouca 
de Aguiar, onde surge em número significativo. Esta aproximação é, porém, quebrada quando introduzimos o factor decorativo. Com efeito, naquela região os esféricos apresentam altos índices de decoração, o que lhe confere um lugar único no contexto calcolitico peninsular, como demonstrou Susana Jorge (Jorge, 1986). Além disso, a técnica decorativa raramente corresponde à aplicação de mamilos, contrariando assim o que ocorre nos raros exemplares decorados, quer do Ramalhão, quer dos povoados mesetenhos a que nos referimos (JoRge, 1986, 378). É ainda possível paralelizar com povoados do Neolítico Final e Calcolitico do Sul de Portugal, tais como Vale Pincel II (Sines) e Cabeço da Mina (Torrão) (Silva e SoAREs, 1976-77), onde surge em percentagens médias.

O nosso tipo 2 encontra paralelos nos mesmos povoados a que aludimos quando tratámos do tipo 1, mas com diferente significado. Este tipo, o mais bem representado no Ramalhão, apresenta idêntica posição em Peña del Aguila e Teso del Moral (Lopez Plaza, 1979, 76), o que já não acontece na Vinha da Soutilha,

S. Lourenço ou Pastoria (Chaves). Neste grupo de povoados do Norte de Portugal, destaca-se o de Castelo de Aguiar (Vila Pouca de Aguiar) por apresentar uma percentagem significativa de taças em calote (Jorge, 1986, 613, 622). Por este motivo, o Ramalhão aproxima-se dum outro povoado do Norte de Portugal, da sua área mais oriental, recentemente estudado, o povoado do Cunho (SANChes, 1988). Aqui, dominam as taças em calote, com diversas variantes, tal como no Ramalhão. Com este factor podemos aproximar todos estes povoados com os do Sul, como Cabeço da Mina (Torrão), Vale Pincel II (Sines), Monte Novo (Sines), Cortadouro (Ourique) (SILva e SoARes, 1976-77) ou Caramujeira (Lagoa) (Gomes et olii, 1978). Se passarmos a analisar alguns contextos sepulcrais, verificamos que este tipo, equivalente ao grupo 4 dos Leisner, é dos mais frequentes no Calcolitico megalítico de Reguengos (LeISNer, 1951, 89) e igualmente conhecido nos monumentos megalíticos da Beira Baixa, como a «Pedra d'Anta» (Medelim), já destruído, e a Anta da Urgueira (Perais) (PEReira, 1933 e BAptista, 1983).

No tipo 3 incluímos as taças carenadas que, no Ramalhão, se encontram mal representadas, o que poderá testemunhar um certo arcaísmo. Nos povoados do SO da Meseta a que nos temos vindo a 
referir, este tipo encontra-se completamente ausente, embora surja noutros nesta mesma região, como os de EI Cerro del Ahorcado, (Zamora), Pozas (Zamora) e Santa María (Ávila), que reúnem, aliás, outras formas carenadas (Lopez PlazA, 1979, 80-81). No Norte de Portugal, este tipo é estranho aos contextos calcolíticos, surgindo numa fase já bastante tardia. Pelo contrário, e como é do conhecimento geral, a taça carenada surge no SO da Península e, particularmente no Alentejo e Algarve, em contextos do Neolítico Médio/Final e Calcolitico Inicial, como o Cabeço da Mina, Vale Pincel II (SIlva e SoARes, 1976-77), Caramujeira II (Gomes et alii, 1978), Parede I (SERrão, 1983) e estrato B da Lapa do Fumo (Serrão e Marques, 1971), etc. O povoado de Papa Uvas I (Huelva) oferece também bons paralelos formais para este tipo (Martín de la Cruz, 1985). Na Extremadura espanhola, os povoados de Araya (Mérida) e EI Lobo (Badajoz) contam igualmente com este tipo entre as suas formas cerâmicas (ENRíquez NAvascuéz, 1981-1982 e 1988; ENRíQuez NAVASCuÉz e InÊSTA Mena, 1985). Nesta mesma região fronteiriça, encontramos ainda este tipo em diversos dólmenes de Valencia de Alcântara (Bueno RAMirez, 1988), a que podemos associar outros da zona de Reguengos, com utilização do Calcolitico Inicial/Médio, como os grandes dólmenes de corredor e câmara trapezoidal ou poligonal de Gorginos I, Paço I e anta grande do Olival da Pega (Leisner, 1951).

Para o nosso tipo 4 -tipo, aliás, bastante mal representado no Ramalhão, não atingindo os 3\%-é bem mais difícil encontrar paralelos. A nível regional, encontramos os melhores paralelos no dòlmen de Corchero (Valencia de Alcântara), de câmara circular e corredor (BUeno Ramirez, 1988, 89) e no megalitismo de Reguengos, através do grupo 2 dos Leisner, que reúne esféricos achatados (LeISNer, 1951). No povoado mesetenho de Cerro del Ahorcado é também possível encontrar algumas formas aparentadas com a nossa (Lopez Plaza, 1979, 82). Por fim, é igualmente legítimo estabelecer possíveis relações formais com o tipo 7 definido para o povoado, da região de Chaves, da Vinha da Soutilha (Jorge, 1986, Fig. 10) e com o tipo 4 da Fraga d'Aia (S. João da Pesqueira) (Jorge et alii, 1988, Fig. 7).

Definimos o tipo 5 pela presença de um único exemplar de que se desconhece o bordo. Este tipo está escassamente representado 
em contextos do Neolítico Final e Calcolitico, anunciando formas que vão ter grande aceitação na Idade do Bronze. Podemos paralelizá-lo com o grupo 6 dos Leisner (Leisner, 1951, Est. XXVII), aliás com uma percentagem muito inferior às dos outros grupos. Estes vasos de fundo convexo encontram-se também no estrato B da Lapa do Fumo (Serrão e Marques, 1971, Fig. 9) e na Meseta, em EI Cerro del Ahorcado e Pozas (Lopez Plaza, 1979-82).

O tipo 6 regista-se em múltiplos contextos neolíticos e calcolíticos de ampla diversidade espacial, não constituindo, por isso, um tipo com expressão cronológico-cultural significativa.

No tipo 7 incluímos os fundos planos, a que se devem ligar as formas que integram o nosso tipo 8. Para ambos se encontram paralelos nos povoados da Meseta e do Norte de Portugal a que já fizemos referência (o tipo 7 é bastante mais raro que o tipo 8), mas são desconhecidos ou têm expressão quase nula nos contextos meridionais estudados por Carlos Tavares da Silva e Joaquina Soares.

O tipo 9 está representado por um só exemplar e corresponde a uma colher. Apresenta-se fragmentada, com cabo horizontal, partido, de secção sub-circular e com duas pequenas depressões laterais na zona de ligação à concha; esta, pouco profunda, está esboroada; teria tido um contorno oval. $O$ nosso exemplar cabe na segunda variante do tipo 9 dos Leisner (cabo partindo horizontalmente do bordo), tipologia que atende somente à forma do cabo e sua posição, mas não ao tipo de concha (LEISNER, 1957, 100-101). Este tipo cerâmico é, de um modo geral, raro, mas com uma notável dispersão geográfica. Encontramo-lo, assim, desde o Chasseense da bacia parisiense e o «Grupo de Gord» (Picardia), onde é bastante abundante (BRIARD, 1989, 109-112), até ao extremo ocidental da Península. A sua origem deve procurar-se no Neolítico Pleno, como provam os exemplares estratigrafados de Los Murciélagos (Córdova) (Vicente Zaragoza e Muñoz amibilia, 1973, Fig. 15) e outros, perdurando pelo Calcolitico e Bronze Inicial, em Los Castillejos de Peña de los Gitanos (Granada) (Arribas e Molina, 1977, 395), Los Castillejos (Badajoz) (Fernández Corrales et alii, 1988, 71), Peña del Aguila (Avila) (Lopez Plaza, 1974, Fig. 1 e 1979, 77), Cuesta del Negro (Granada) (Molina e Pareja, 1975, Fig. 31), Cerro de la Virgen (Granada) 
(Schule e Pellicer, 1966, 56), etc. No territòrio actualmente português, este tipo surge não só em contextos habitacionais mas também sepulcrais. Entre os primeiros, contam-se os exemplares do Cabeço da Mina (Torrão) (Silva e Sosres, 1976-77, 203-204), Monte da Tumba (Torrão) (Silva e SoAres, 1987, 53, 55, 63), Cunho (Mogadouro) (SAnches, 1988, 154), Vila Nova de São Pedro (ref. Leisner, 1951, 100; no Museu Arqueológico da Associação dos Arqueólogos Portugueses encontram-se em exposição cinco colheres de Vila Nova de São Pedro), e Castelo Velho do Caratão (Mação) (Pereira, 1970, 130). Para os segundos, além do exemplar do dòlmen de Rio Torto (Gouveia) atribuído à Idade do Bronze (SEnNa-Martinez, 1983-84, 118, 122), contam-se outros entre os monumentos megalíticos de Reguengos e de outras regiões do Sul de Portugal. A título de exemplo, podemos referir as colheres da anta do Barrocal (Leisner, 1959, Est. 40), anta 1 do Passo, anta 1 de Gorginos e anta grande do Olivai da Pega (Leisner, 1951, 45); anta da Marquesa (Marvão), anta dos Galvões (Alandroal) e anta da Casa Branca (Pavia) (Leisner, 1951, 45). Também na vizinha Espanha encontramos um exemplar deste tipo no dolmen de Corchero (Valencia de Alcantara) (Bueno Ramirez, 1988, 166) e no povoado de Peña del Aguila (Lopez Plaza, 1979, 77). Aponte-se, ainda, um exemplar proveniente do Cabeço da Amoreira (Muge), sem contexto conhecido (Cortez, 1952, 199, 202; Ferreira, 1974, 192) ${ }^{(12)}$. Refira-se finalmente, que o número de colheres provenientes das estações enumeradas é sempre de um ou dois exemplares por estação.

A título conclusivo, poderemos dizer que a cerâmica do Ramalhão, não obstante a relativa heterogeneidade de tipos - foram definidos nove tipos diferentes —, acaba por apresentar, dum modo geral, uma certa monotonia em termos formais, com base em formas primárias e muito simples. Por outro lado, o estudo comparativo que fizemos e que não pretendeu ser exaustivo, confirmou a associação, neste povoado da Beira Baixa, de formas e

(ia) Spindler refere uma colher do Cabeço da Amoreira, por certo a mesma aqui mencionada, embora apresente desenho de uma colher do Cabeço da Arruda (S Pinde er, 1981, 27, 31, 34). 
tipos comuns a outras regiões: taças de diversos tipos, frequentes em contextos neolíticos e calcolíticos meridionais, esféricos e globulares, com ou sem colo marcado, com maior expressão em contextos coevos do Norte de Portugal e com uma posição igualmente favorável em vários povoados do $\mathrm{SO}$ da Meseta, que testemunham, por sua vez, influências meridionais na opinião de Lopez Plaza $(1979,102)$.

No que respeita à cerâmica decorada do Ramalhão, regista-se um baixo índice, com apenas $1,2 \%$, relativamente à lisa. Distribui-se pelos sectores IV, V e VIII, com duas variedades: decoração plástica e decoração incisa associada a puncionamentos.

A decoração plástica apresenta-se sob a forma de pequenos mamilos arredondados ou ovoides, dispostos sob o bordo, ou de mamilos alongados que arrancam verticalmente do bordo; esta segunda variante só está presente no sector VIII. Ambas se associam aos nossos tipos 1 e 2 .

O baixo índice de cerâmica decorada, por um lado, e a aplicação de mamilos sob o bordo dos recipientes, por outro, aproxima o povoado do Ramalhão de outros da Extremadura espanhola, SO da Meseta e Alentejo. Por exemplo, no povoado de Araya (Mérida), com uma ocupação atribuível ao Calcolitico Inicial, a cerâmica decorada não chega a atingir 1\% (ENRíquez NAvascués, 1981-82 e 1988); em Peña del Aguila (Avila) e Aldeagordillo (Avila), a cerámica decorada é igualmente escassa (Lopez Plaza, 1974, 125 e 1979, 81); ocorre o mesmo no Cabeço da Mina e Vale Pincel II (Silva e Soares, 1976-77, 195 e 213).

A associação dos mamilos a formas esféricas ou semi-esféricas adverte-nos para uma provável ascendencia neolítica destas cerámicas.

A cerámica incisa está representada por um único fragmento de bordo de uma taça em calote, proveniente do sector IV. Está decorada com triângulos incisos que se desenvolvem a partir do bordo, invertidos e abertos, e preenchidos internamente por puncionamentos simples. Este motivo, tendo por base o triángulo e múltiplas variantes, verdadeiramente notável nos povoados da região de Chaves, aparece bem documentado em contextos habitacionais e sepulcrais desde o chamado «Neolítico das Grutas» até ao «Horizonte de Cogotas I», na sua fase mais antiga, do Bronze 
Médio e Tardio (Fernández Posse, 1980, 617). Apresenta, portanto, corno outros elementos já analisados no presente estudo, um valor cronológico-cultural bastante vago.

Podemos referir alguns paralelos nas regiões vizinhas, provenientes de povoados do Calcolitico Inicial de Araya (Mérida), Peña del Aguila (Avila), ou mais tardios, como Aldeagordillo (Avila) (EIroA, 1973, Fig. 3), Los Cortinalles (Badajoz) (Gil-Mascarell Boscá e Rodríguez díaz, 1988, 61) ou Las Pozas (Zamora) (Martín Valls e Delibes de Castro, 1975, 450). Cabe também aqui informar da existencia de um fragmento decorado com um triângulo inciso e invertido, preenchido com pontilhado, proveniente do povoado do Cabeço Pelado (Alcains), exposto no Museu de Tavares Proença Júnior, em Castelo Branco.

No Norte de Portugal, o nosso exemplar aproxima-se da variante Il-b da Vinha da Soutilha (Chaves), da sua primeira fase, onde a decoração é ainda pouco invasora (JoRge, 1986, 93, 696, 779).

Justifica-se, finalmente, uma breve referência aos monumentos megalíticos mais próximos onde se observa este mesmo tema decorativo : no grupo de Reguengos vamos encontrá-lo quase exclusivamente documentado na anta grande do Olival da Pega (LeISNer, 1951, 105); no conjunto megalítico de Valência de Alcântara surge no dòlmen de Datas II (Bueno Ramírez, 1988, 166).

\section{Considerações finais}

Os elementos recolhidos durante as duas campanhas de escavação que realizámos no Ramalhão permitem-nos avançar com alguns princípios caracterizadores deste povoado, embora admitamos a conveniência em usar da máxima prudência na sua interpretação.

A presumível cronologia do Bronze Final atribuída a este povoado, a partir da análise de escassos materiais de superfície (Leitão, 1982 e Baptista, 1982), deverá ser hoje posta de lado, face aos únicos materiais disponíveis e que este trabalho pretendeu 
divulgar. Não só não encontrámos qualquer pista que sugerisse tal cronologia, como reunimos um acervo de material, nomeadamente cerâmico, que, não obstante as suas limitações de natureza cronológico-cultural, contraria, de qualquer modo, aquela cronologia. Aponta antes, para uma ocupação bastante mais arcaica, nomeadamente de ascendência neolítica, como provam as formas simples e primárias, e a decoração, rara, à base de mamilos e triângulos incisos.

A valorização que atribuímos ao estudo da cerâmica decorreu das condições de jazida com que deparámos, que, com excepção duma pequena área do sector VIII, correspondiam à acumulação de material de escorregamento, não tendo sido detectadas associações significativas ou estruturas de habitat; foi definida para todos os sectores intervencionados uma única fase de ocupação. A atenção dispensada à cerâmica resultou ainda das características do material litico (polido e lascado), dum modo geral atípico, incaracterístico ou com uma distribuição espacial e cronológica demasiado ampla para fornecer dados precisos.

A cerâmica exumada, maioritariamente lisa, caracteriza-se por uma grande homogeneidade técnica que contrasta com uma morfologia variada, a que correspondem nove tipos. O seu estudo comparativo com estações de que se conhece a cronologia, com base em datações absolutas ou relativas, como Cabeço da Mina (Torrão), Vale Pincel II (Sines) (SILva e SoARes, 1976-77), estrato B da Lapa do Fumo (Sesimbra) (Serrão e Marques, 1971), Parede I (SERrão, 1983), Caramujeira (Lagoa) (Gomes et olii, 1978), Vinha da Soutiha, S. Lourenço (Chaves), Castelo de Aguiar (Vila Pouca de Aguiar) (Jorge, 1986), Peña del Aguila (Ávila) (Lopez Plaza, 1979), Araya (Mérida) (Enríquez Navascués, 1988), Los Barruecos (Cáceres) (Sauceda Pizarro, 1986) ou Papa Uvas (Huelva) (MARTín de La Cruz, 1985), etc., leva-nos a apontar, apesar dos condicinalismos já referidos, uma ocupação do Neolítico Final/Calcolítico para o povoado do Ramalhão, a situar na primeira metade do III milénio a. C.

Assim sendo, este povoado constitui uma das mais antigas provas de sedentarização conhecidas, até ao momento, nesta região da Beira Baixa. Para já, não são ainda conhecidos outros povoados contemporâneos no concelho de Penamacor, embora alguns achados 
recentes (13) na Lagoa, Marvão, Covões, Senhora da Quebrada (Benquerenças) e Fonte Salgueira (Aldeia do Bispo), deixem adivinhar a provável existência de outros locais com possível ocupação do Neolítico/Calcolítico.

Também na parte sul do distrito de Castelo Branco têm surgido novos elementos através da acção do N. R. I. A. $\left({ }^{14}\right)$, que se tem pautado por uma eficaz e sistemática identificação de estações arqueológicas, importando aqui referir os povoados de Peroledo, Cabeça Velha e Charneca de Fratel (Vila Velha de Ródão), actualmente em estudo (Henriques et alii 1986; SoAres, 1988). A sua provável correlação com monumentos megalíticos e estações de arte rupestre parece evidente, o que aliás se repete na outra margem do Tejo, já no concelho de Nisa (Caninas e Henriques, 1987).

Para o período cronológico que estamos a tratar, foram definidos dois modelos de povoamento em função da localização topográfica dos povoados (SILva e SoARes, 1984). A posição de domínio que ocupa o povoado do Ramalhão, na coroa do monte, aproxima-o do modelo de habitat que irá dominar durante o Calcolitico, com evidentes preferências por sítios altos e dominantes, e a que corresponderia uma nova organização social de feição tribo-patriarcal acompanhada por um aumento de produção e acumulação de excedentes (Silva e SoAres, 1984). Ora este modelo de habitat, frequentemente aliado a estruturas defensivas $\left({ }^{15}\right)$, convive durante algum tempo com outros que, ocupando zonas baixas e abertas, revelam realidades sociais e económicas diferentes.

Apesar de reconhecermos a relativa fragilidade de alguns dos dados reunidos, podemos sugerir, numa primeira análise, que no Ramalhão se instalou uma comunidade humana com carácter

(13) Agradecemos a José Cristóvão, aluno da variante de Arqueologia da FLUC, as informações prestadas sobre este assunto. Os materiais, líticos e cerâmicos, estão a ser estudados por Ana Cristina Farinha, também aluna da variante de Arqueologia.

(14) Núcleo Regional de Intervenção Arqueológica, sediado em Vila Velha de Ródão.

(15) A nível regional, constituem bons exemplos deste modelo os povoados de Charneca de Fratel (Vila Velha de Ródão), Los Barruecos (Cáceres), Los Castillejos e Los Cortinalles(Badajoz). 
sedentário, pese embora a provável natureza precária das suas estruturas, que praticaria uma agricultura de que constituem testemunhos indirectos os machados, a enxó e os elementos de moinho.

Desconhecemos se, na sua alimentação, a domesticação de animais teria tido um papel importante, uma vez que os pequenos fragmentos ósseos provenientes do sector VIII não foram ainda estudados $\left({ }^{16}\right)$.

No que diz respeito à origem da matéria-prima utilizada no fabrico de instrumentos, toda ela é de fácil obtenção local ou regional.

Esta comunidade não deixou, pois, testemunhos de grande abertura ao exterior, mas, antes, sinais de um regionalismo conservador, apesar de já anunciar, pela sua situação e posição, os novos ventos de mudança que dominarão durante o Calcolitico.

${ }^{16}$ ) Os fragmentos ósseos encontram-se num estado de elevada fragmentação que dificultará o seu estudo. 


\section{BIBLIOGRAFIA}

Arribas, A. e Molina, F. (1977), El Poblado de los Castillejos, en las Peñas de los Gitanos (Montefrio, Granada). Resultados de las campañas de 1971 e 1974, «XIV Congreso Nacional de Arqueologia» (Vitoria, 1975), Zaragoza, p. 389-406.

Balfet, H. et alii (1983), Pour la Normalisation de la Description des Poteries, Paris, C.N.R.S.

Baptista, J. (1982), Subsídios para a Carta Arqueológica do Concelho de Penamacor até ao domínio romano, "Actas e Memórias do $1 .^{\circ}$ Colóquio de Arqueologia e História do Concelho de Penamacor (1979)», Penamacor, p. 73-79.

Idem, (1983), Subsídios para o estudo do megalitismo da Reira Raixa. A Anta da Urgueira, "O Archeologo Português», série IV, voi. 1, p. 89-102.

Briard, J. (1989), Poterie et Civilisations - T. 1. Néolithique de la France, Paris, Éditions Errance.

Bueno Ramirez, P. (1988), Los Dólmenes de Valencia de Alcantara, Excavaciones Arqueológicas en España, 155, Madrid.

Ca mps, G. (1981), Manuel de Recherche Préhistorique, Paris, Doin Éditeurs.

Caninas, J. C. e Henriques, F. J. R. (1987), Testemunhos do Neolítico e do Calcolitico no Concelho de $N$ isa, "Actas das 1. as Jornadas de Arqueologia do Nordeste Alentejano (1985)», p. 69-82.

Caninas, J. e Henriques, F. (1988a), Povoado Pré-Histórico da Charneca de Vilar de Roi - Peroledo, «Paleoantropologia e Paleoecologia no Alto Tejo Português - Imóveis de Interesse Cultural e Natural», n. ${ }^{\circ}$, NIRA, GEPP, MAEDS.

Caninas, J. e Henriques, F. (1988b), Povoado Pré-Histórico da Cabeça Velha, «Paleoantropologia e Paleoecologia no Alto Tejo Português - Imóveis de Interesse Cultural e Naturai», n. ${ }^{\circ}$, NIRA, GEPP, MAEDS.

Cortez, F. R. (1952), Contributo para o Estudo do Neolítico em Portugal, «Trabalhos de Antropologia e Etnologia», voi. XIII (3-4), Porto, p. 193-248.

Eiroa, J. J. (1973), Noticia de un yacimiento de la Edad del Rronce en Aldeagordillo (Avila), «XII Congreso Nacional de Arqueologia (Jaén, 1971)», Zaragoza, p. 233-240.

Enriquez Navascués, J. J. (1981-1982), Avance al estudio de los materiales procedentes de Araya, Mérida (Radajoz), «Pyrenae», 17-18, p. 191-202.

IDEM (1988), Informe sobre las excavaciones llevadas a cabo en el yacimiento de Araya (Mérida, Radajoz) — 1983-1984, «Extremadura Arqueológica», I, Salamanca, p. 11-19.

EnRíquez NaVASCués, J. J. e Inêsta Mena, J. (1985), Notas sobre los poblados calcolíticos de la comarca de Lerena (Badajoz), «Estudios de Arqueologia Extremeña (Homenaje a Canovas Pesini), 1, Badajoz, p. 15-24.

Conimbriga, 28 (1989), 5-32 
Fernández Corrales, J. M. et alii (1988), Los poblados caleolíticos y prerromano de «Los Castillejos» (Fuente de Cantos, Badajoz), «Extremadura Arqueológica», I, Salamanca, p. 69-88.

Fernández-Posse y de Arnaiz, M. D. (1939), El Final de la Edad del Bronce en la Meseta Norte: la Cultura de Cogotas I, Universidade de Granada.

Ferreira, O. V. (1974), Acerca das cerámicas neolíticas encontradas na parte superior dos concheiros da região de Muge (Portugal), "Comunicações dos Serviços Geológicos de Portugal», LVIII, p. 191-195.

Gil-Mascarell Boscá, M. e Rodríguez Díaz, A. (1988), Los Cortinales, un yacimiento calcolitico en Villafranca de los Barros (Badajoz), «Extremadura Arqueológica», I, Salamanca, p. 55-68.

Gомеs, M. V. et alii (1978), A estação pré-histórica da Caramujeira - Trabalhos de 1975/76, «Actas das III Jornadas Arqueológicas (1977)», vol. I, Lisboa, p. 35-72.

González Cordeiro, A. e Alvarado gonzalo, M. (1988), El poblado calcolitico del Cerro de la Horca - Plasenzuela (Caceres) - 1. ${ }^{\text {a }}$ campaña de excavaciones, «Extremadura Arqueológica», I, Salamanca, p. 21-34.

Henriques, F. et alii (1986), Carta Arqueológica do Concelho de Vila Velha de Bódão, «Informação Arqueológica», n. ${ }^{\circ}$ 6, Lisboa, p. 9-22.

Furtado, V. (1986), El Calcolitico en la Cuenca Media del Guadiana y la Necropolis de la Pijotilla, "Arqueologia», 14, Porto, p. 83-103.

Jorge, S. O. (1986), Povoodos da Pré-História Recente da região de Chaves $V^{a}{ }^{a} .^{a}{ }^{d}$ de $A_{b}$ uiar, Porto.

Jorge, V. O. et alii (1988). A Fraga d'Aia (Paredes da Beira - S. João da Pesqueira) - Arte Rupestre e Ocupação Pré-Histórica, «Trabalhos de Antropologia e Etnologia», XXVIII (1-2), («Actas do Coloquio de Arqueologia do Noroeste Peninsular», vol. I), p. 201-232.

Landeiro, J. M., (1961), A Vila de Penamacor - A Cidade de Asygriavaca - Estradas Romanas, «Numus», Porto, vol. VI (3), n. ${ }^{\circ} 22$, p. 149-152.

Leisner, G. E V. (1951), Antas do Concelho de Reguengos de Monsaraz Materiais para o Estudo da Cultura Megalítica em Portugal, Lisboa, Instituto para a Alta Cultura.

Leisner, G. E V. (1959), Die Megalithgräber der Iberischen Halbinsel-Der Westen, Berlin, Verlag von Walter de Gruyter, Madrider Forschungen.

LEITão, M. (1982), Elementos para um Inventário de Estações Arqueológicas: prospecção e reconhecimento, «Informação Arqueológica», 2, p. 17.

Lopez Plaza, M. S. (1974), Materiales de la Edad del Bronce hallados en Muñogalindo (Avila), «Zephyrus», XXV, p. 121-143.

IDEM (1979), Aportación al conocimiento de los poblados eneolíticos del SO. de la Meseta N. Española: la cerámica, «Setúbal Arqueológica», V, p. 67-102.

Marques, G. (1972), Arqueologia de Alpiarça. As estações representadas no Museu do Instituto de Antropologia do Porto, Trabalhos do Instituto de Antropologia Dr. Mendes Corrêa, n. ${ }^{\circ}$ 13, Porto.

Conimbriga, 28 (1989), 5-32 
Martín de la Cruz, J. C. (1985), Papa Uvas I, Aljaraque, Huelva - Campañas de 1976 a 1979, Excavaciones Arqueológicas en España, 136.

Martín Valls, R. e Delibes de Castro, G. (1975), Hallazgos Arqueológicos en la provincia de Zamora (77), «Boletín del Seminario de Arte y Arqueologia», XL-XLI, p. 445-473.

Molina Gonzales, F. e Pareja lópez, E. (1975), Excavaciones en la Cuesta del Negro (Purullena, Granada) - Campaña de 1971, «Excavaciones en España, n. ${ }^{\circ} 86$, Madrid.

Molina Lemos, L. (1980), El Poblado del Bronce I El Lobo [Badajoz), «Noticiario Arqueológico Hispánico», 9, p. 93-127.

Pereira, F. A. (1933), A Pedra d'Anta ou um monumento megalítico na Beira Baixa, «O Archeologo Português», XXIX, p. 49-75.

Pereira, M. A. H. (1970), Monumentos Históricos do Concelho de Mação, Coimbra.

Piel-Desruisseaux, J.-L. (1984 e 1986), VOutil de Pierre P réhistorique > Paris, Masson.

Proença, F. T. (1910), Archeologia do Districto de Castello Branco, Leiria.

Ramos Millan, (1981), Interpretaciones sequenciales y culturales de la Edad del Cobre en la zona meridional de la Península Iberica. La alternativa del materialismo cultural, "Cuadernos de Prehistoria de la Universidade de Granada», 6, p. 203-256.

Ribeiro, O. et alii (1987), Geografia de Portugal - 7. A Posição Geográfica e o Território, Lisboa. Edições Sá da Costa.

Sanches, M. J. (1988), Contribuição para o Estudo da Pré-História Recente no Planalto Mirandês, Porto, FLUP (edição policopiada).

Sauceda Pizar o, M. I. (1986), Primeros Avances sobre el Calcolitico en Extremadura: Los Barruecos, Malpartida de Cdceres, «Norba», 7, p. 17-23.

Schüle, W. e Pellicer, M. (1966), El Cerro de la Virgen. Orce (Granada) I, «Excavaciones Arqueológicas en España», 46.

Senna-Martinez, J. C. et alii (1983-1984), Contribuições para uma Tipologia da Olaria do Megalitismo das Beiras: olaria da Idade do Bronze (I), «Clio/ /Arqueologia», I, p. 105-138.

Serrão, E. C. (1983), A Estação Pré-Histórica da Parede, «O Arqueólogo Português», série IV, I, p. 119-148.

Serrĩo, E. C. e Marques, G. (1971), Estrato Pré-Campaniforme da Lapa do Fumo (Sesimbra), «Actas do II Congresso Nacional de Arqueologia», Coimbra, I, p. 121-142.

Silva, C. T. e Soares, J. (1976-1977), Contribuição para o Conhecimento dos Povoados Calcolíticos do Baixo Alentejo e Algarve, «Setúbal Arqueológica», voi. II-III, p. 179-272.

Idem (1984), A estratégia do povoamento dos Chãos de Sines durante a Pré. -História, «Volume d'Hommage au Géologue Georges Zbyszewski», Paris, p. 393-410. 
IDEM (1986), Intervenção Arqueológica na Vila do Torrão: Ocupação Calcolitico, «I Encontro Nacional de Arqueologia Urbana (Setúbal, 1985)», Lisboa, Trabalhos de Arqueologia - 03, p. 103-114.

Idem (1987), O Povoado Fortificado Calcolitico do Monte da Tumba - I Escavações Arqueológicas de 1982-86 (resultados preliminares), «Setúbal Arqueológica», VIII, p. 29-79.

Soares, J. (1988), O Povoado da Charneca do Fratei e o Neolítico Final/Calcolítico da Região Ródão-Nisa: Notícia Preliminar, «Alto Tejo», 2, Setembro, NRIA/GEEP/MAEDS.

SPINDLER, K. (1981), Zum Enddatum der Portugiesischen Muschelhaufen, «Madrider Mitteilungen», 22, p. 19-35.

VÁrios (1979), "Actas da 1. ${ }^{a}$ Mesa Redonda sobre o Neolítico e o Calcolitico em Portugal, Porto, GEAP, Trabalhos do Grupo de Estudos Arqueológicos do Porto, n. ${ }^{\circ} 3$.

Vicente Zaragoza, A. M. e Muñoz Amibilia, A. M. (1973), Segunda Campaña de Excavaciones. La Cueva de los Murciélagos, Zuheros (Cordoba), Excavaciones Arqueológicas en España, n. ${ }^{\circ} 77$. 
Mapa morfológico da parte oriental da C. da Beira (0.Ribeiro,1955)

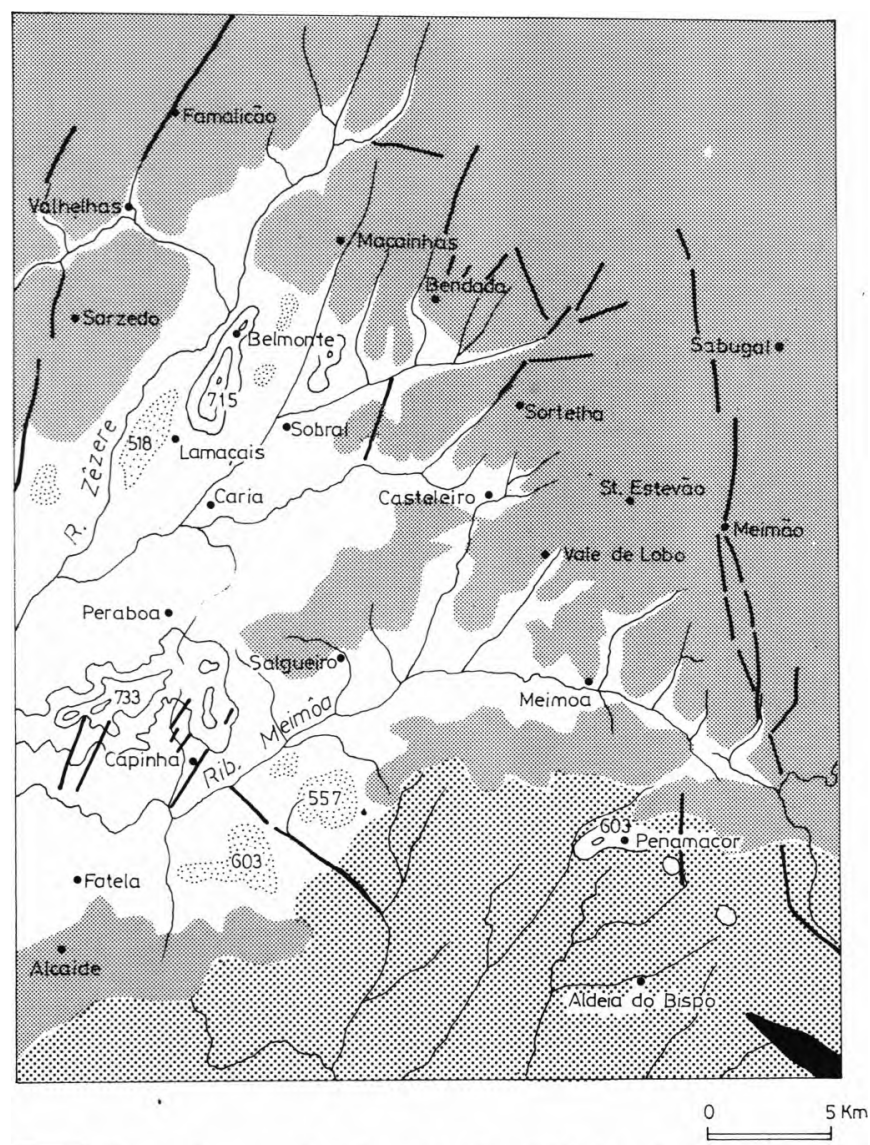

Montanhas e planaltos da Cordilheira Central

Relevos residuais no fundo da depressão

3 Superfície de Castelo Branco

Cova da Beira

Crista de Quartzito

(2) Montes-ilhas (curvas equidistantes de $100 \mathrm{~m}$ )

Vales de fractura 
EST. II

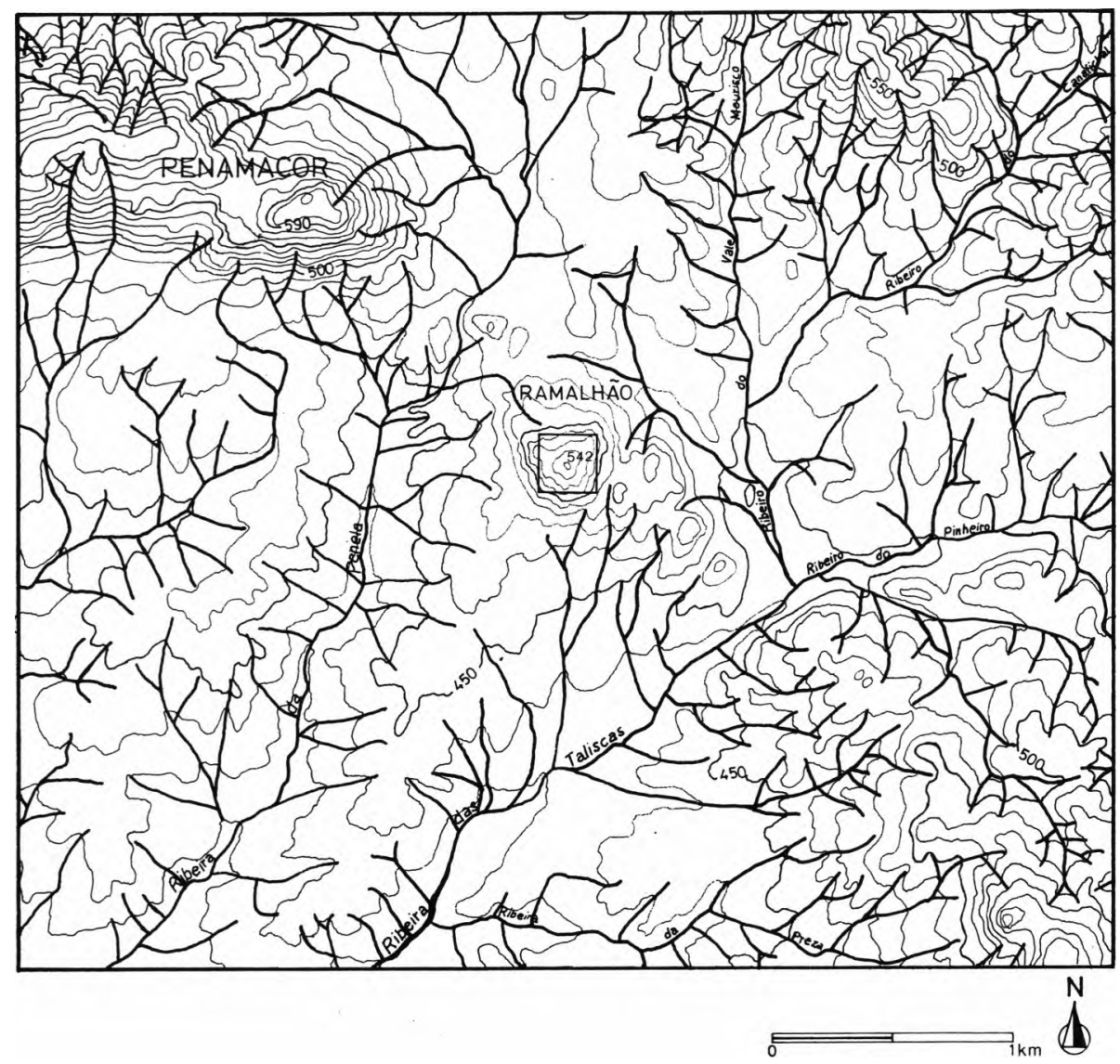


EsT.III

$w \leftarrow T$ c1 $T$ с2 $T$ c3 $T$ c4 $T \rightarrow E$

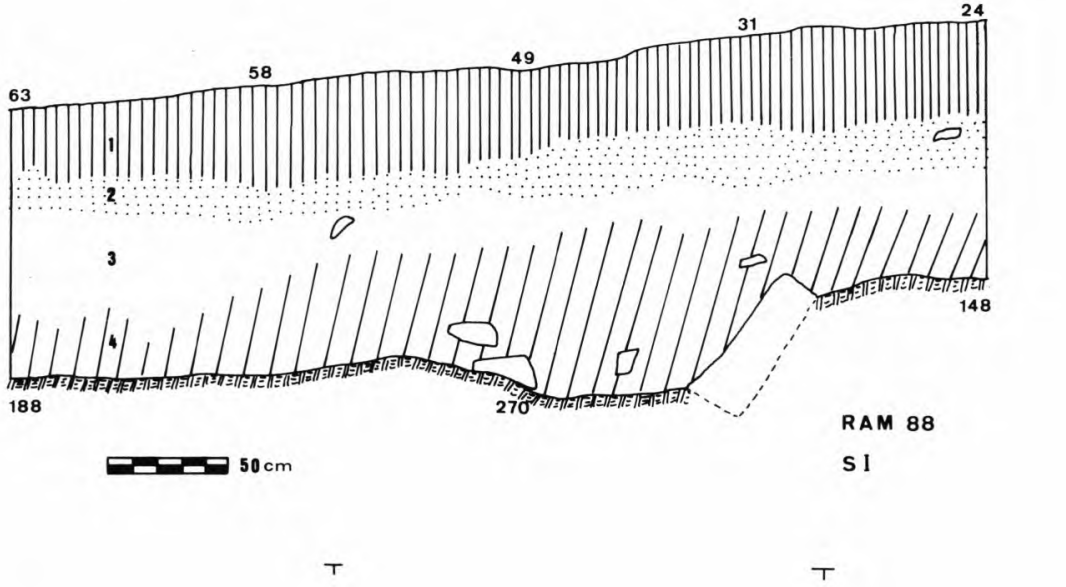

$c_{4}^{\prime}$

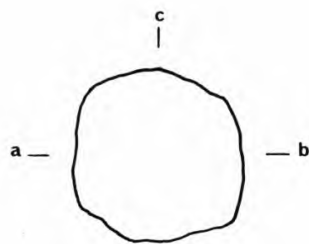

$\dashv$

$\mathrm{D}_{4}^{\prime}$
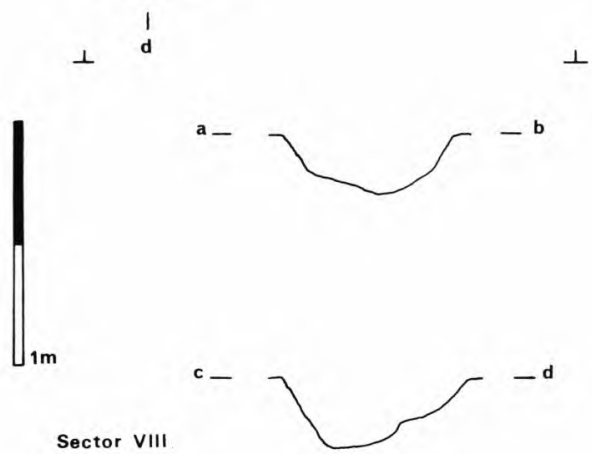
(Página deixada propositadamente em branco) 
Est. IV

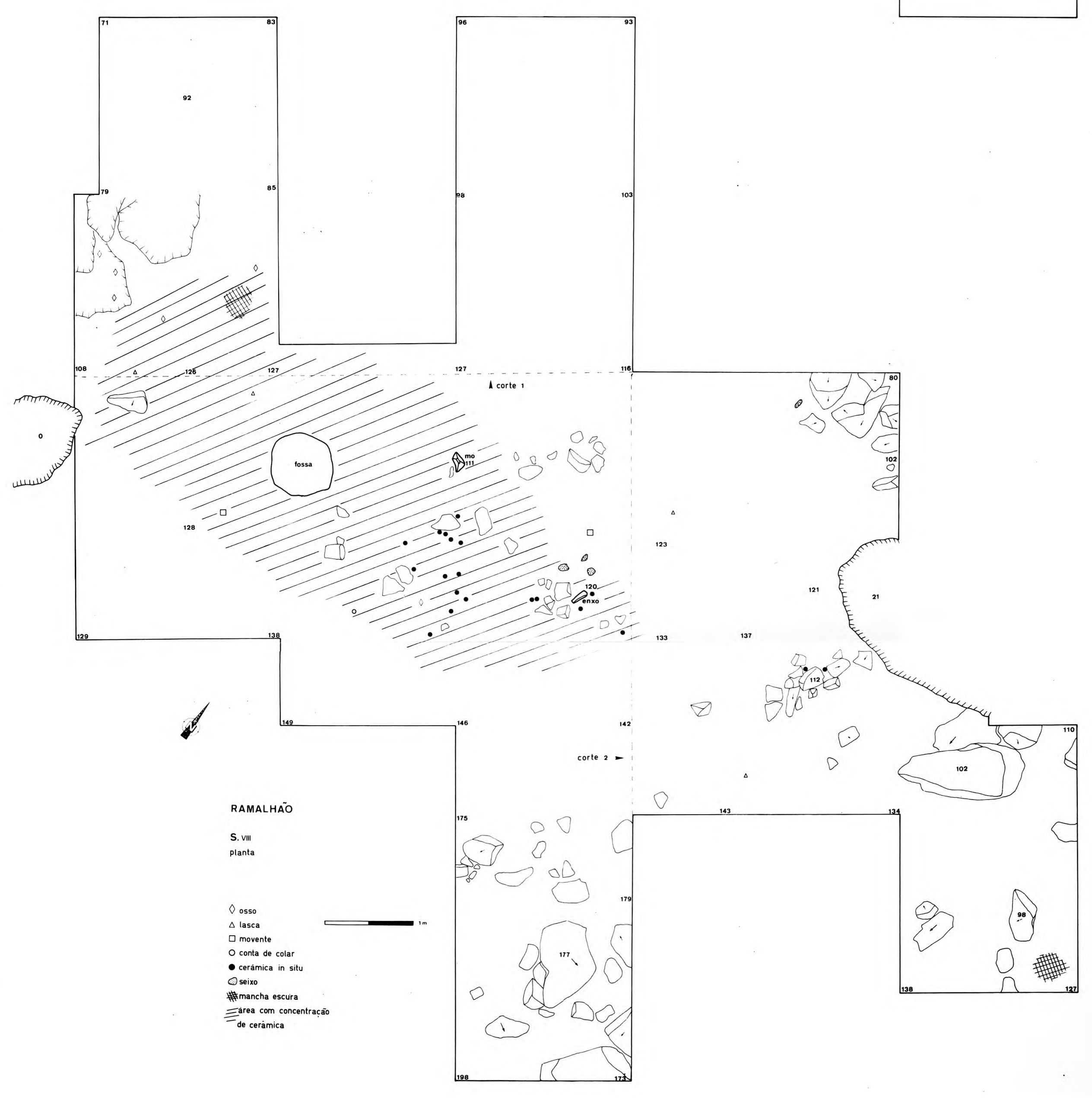


(Página deixada propositadamente em branco) 


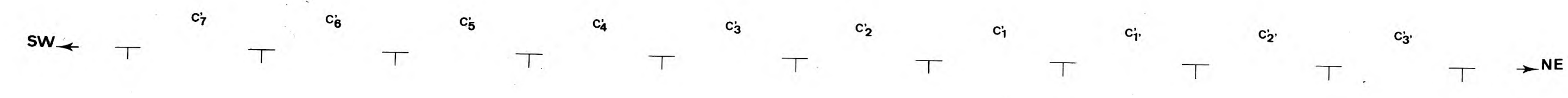

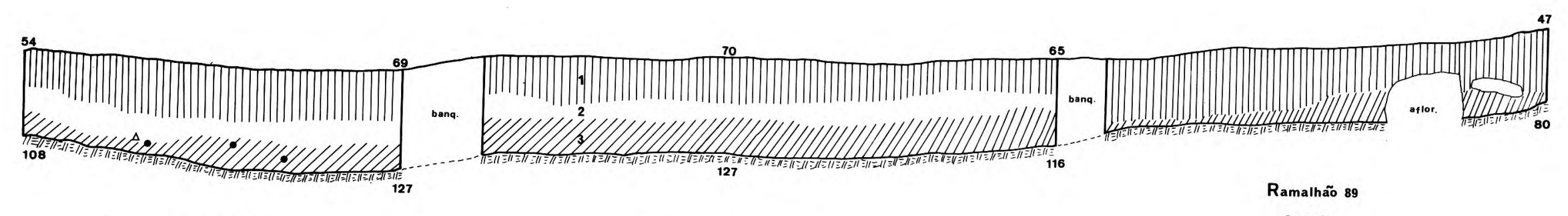

- coriamica

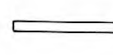

$\longrightarrow$

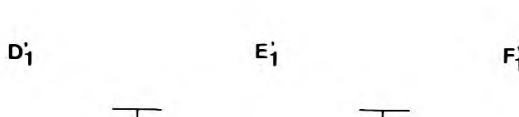

Fi T

$G_{1}$

corre 1

s.w.1.

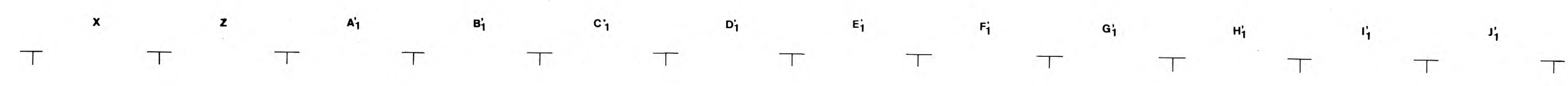

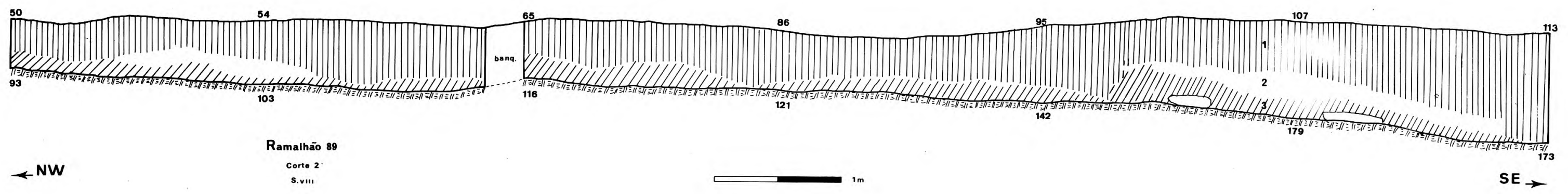


(Página deixada propositadamente em branco) 
Est. VI
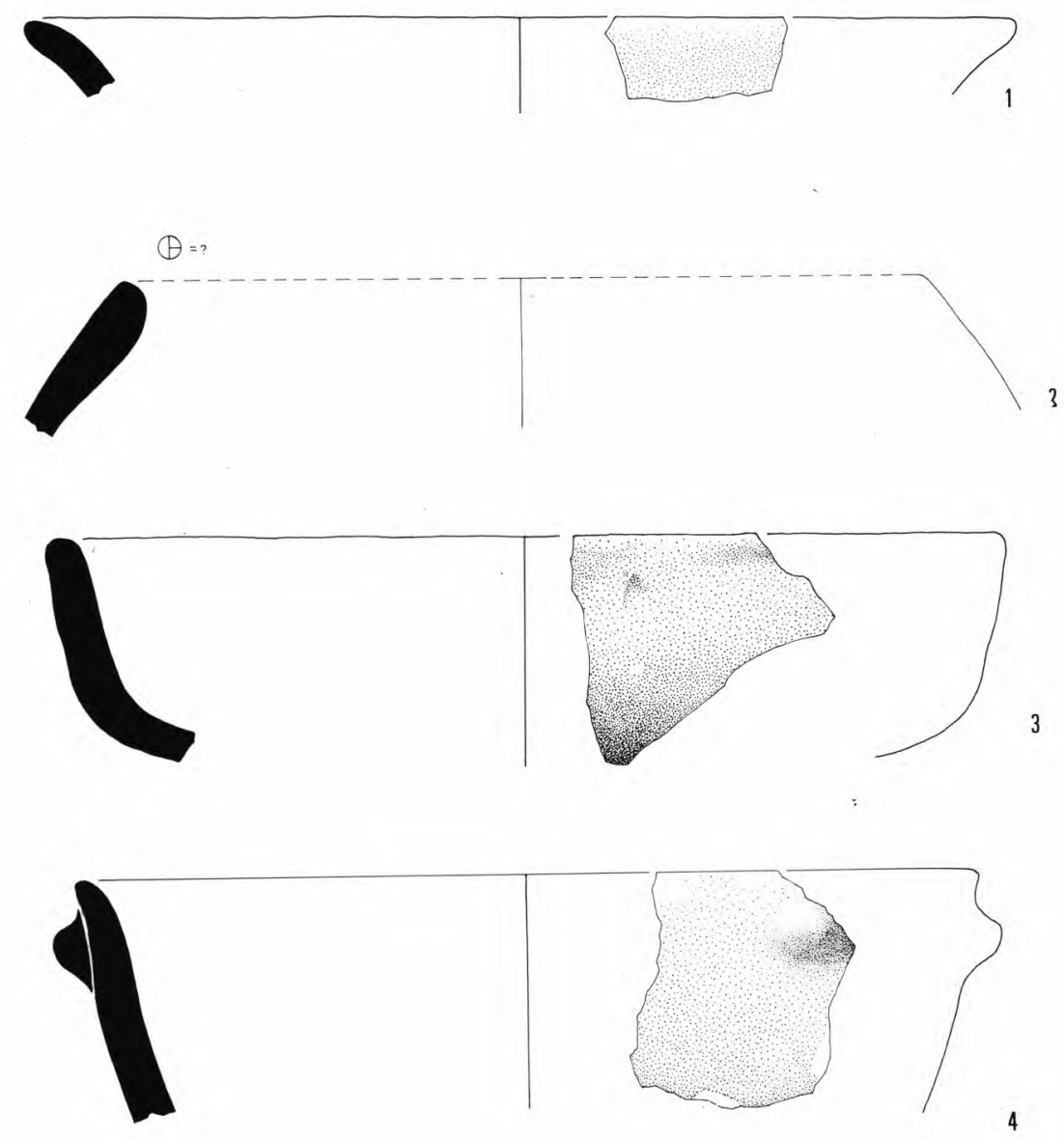

(1)=?
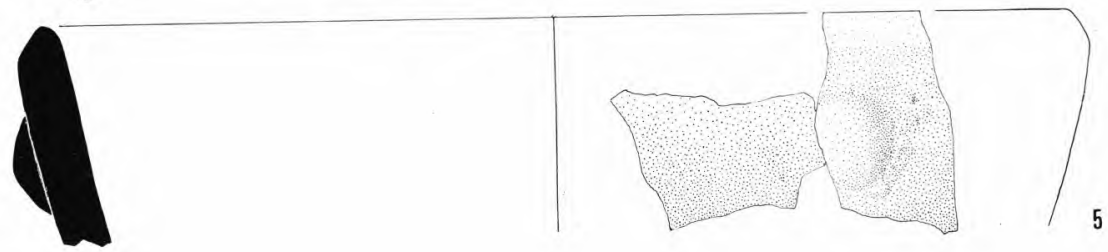

$3 \mathrm{~cm}$ 
EST.VII
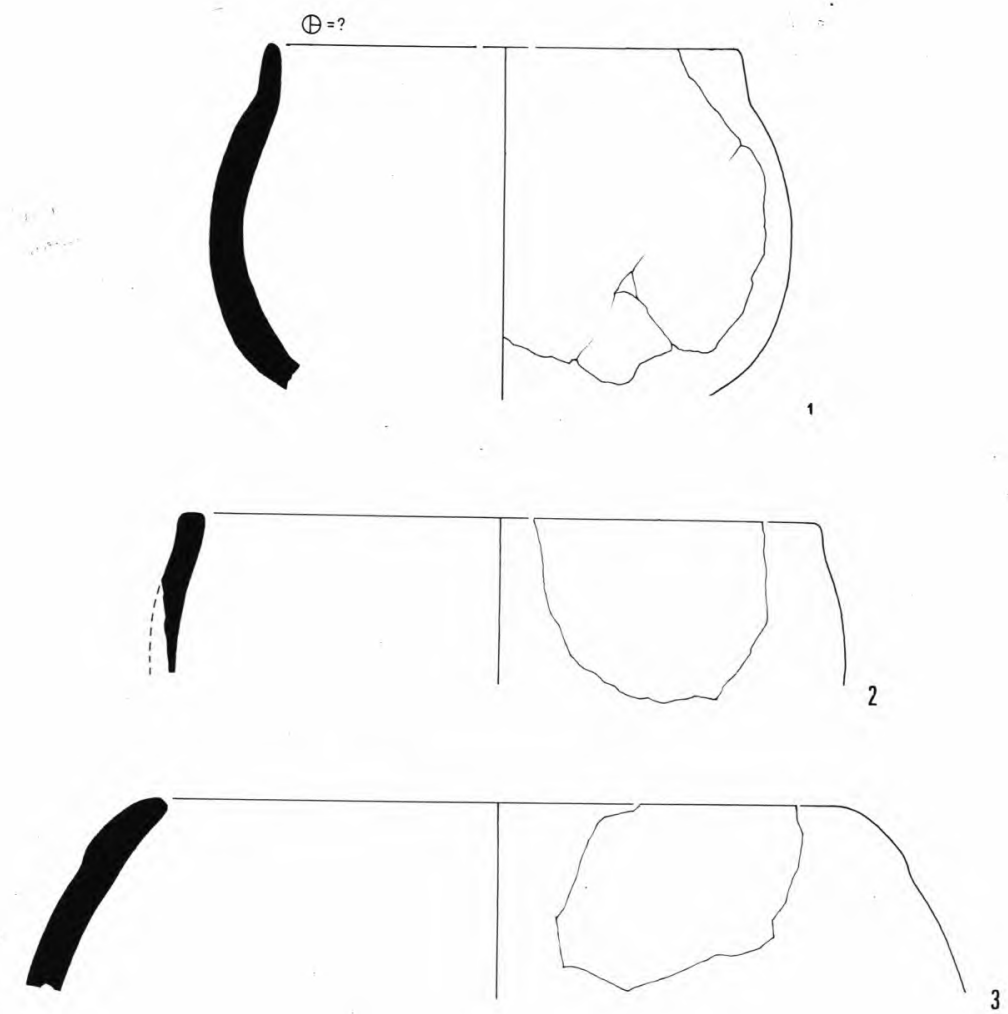

$\theta=2$
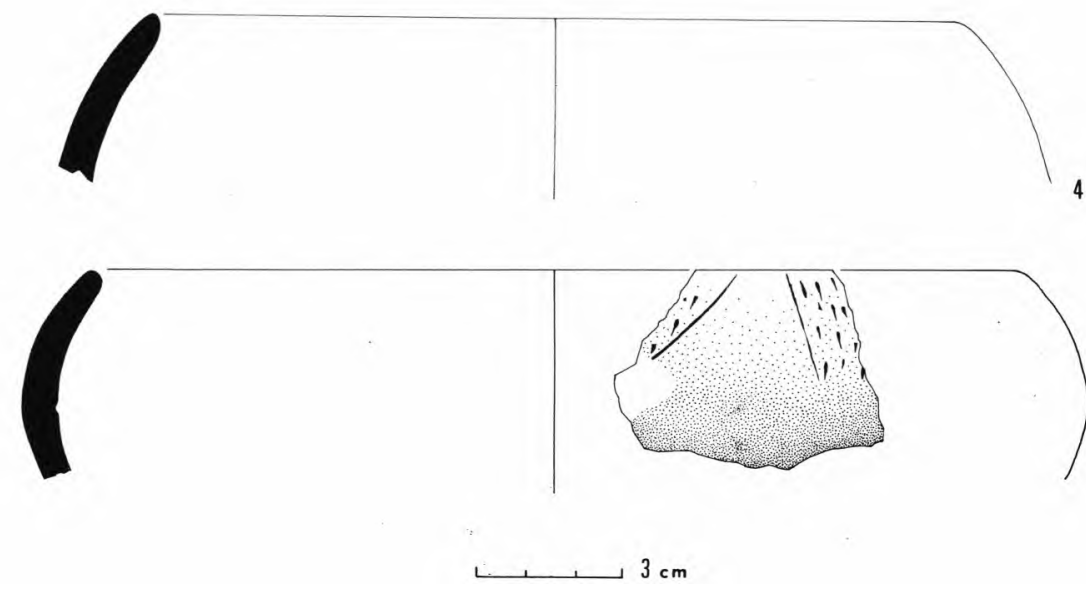
Est. VIII
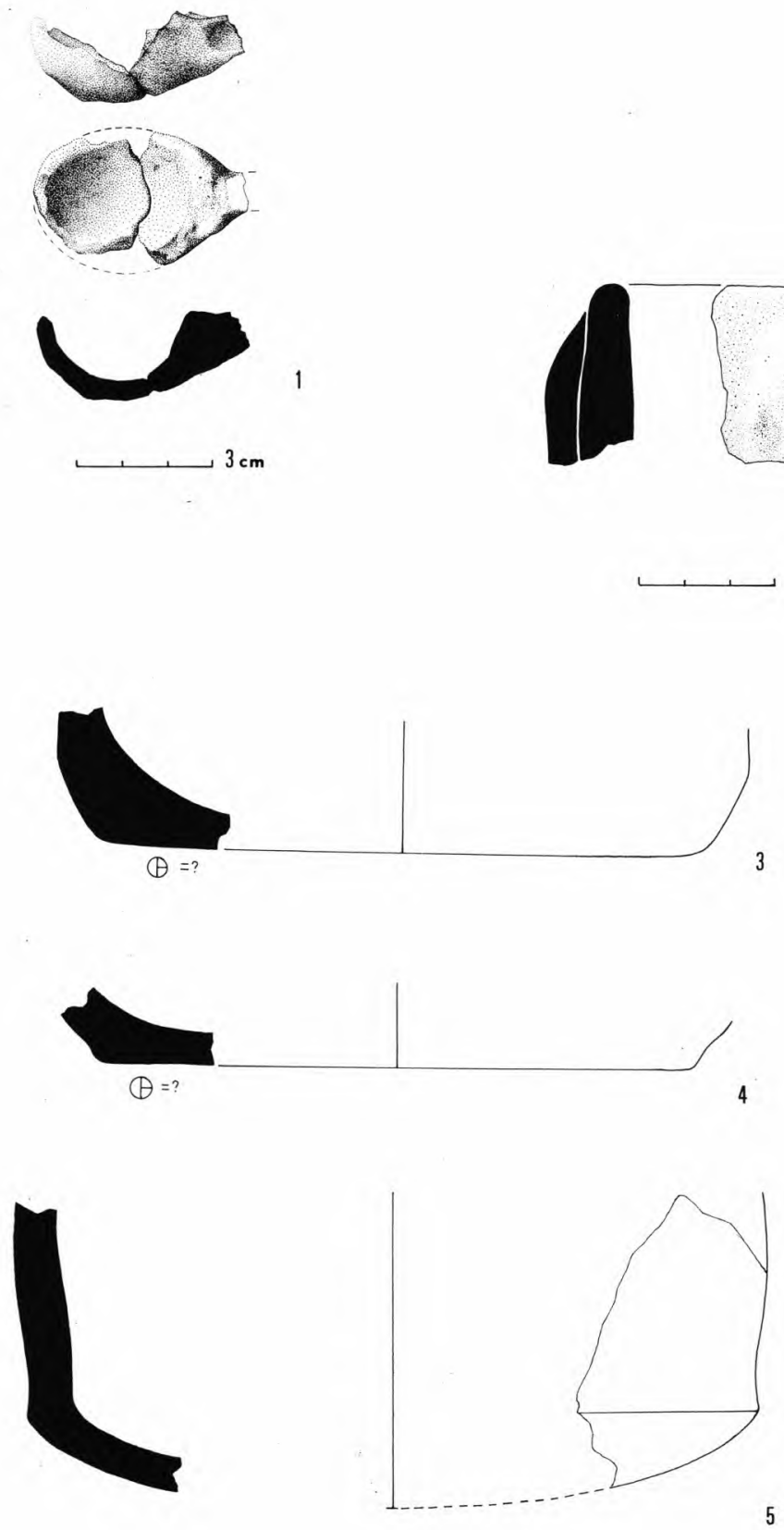
EST. IX
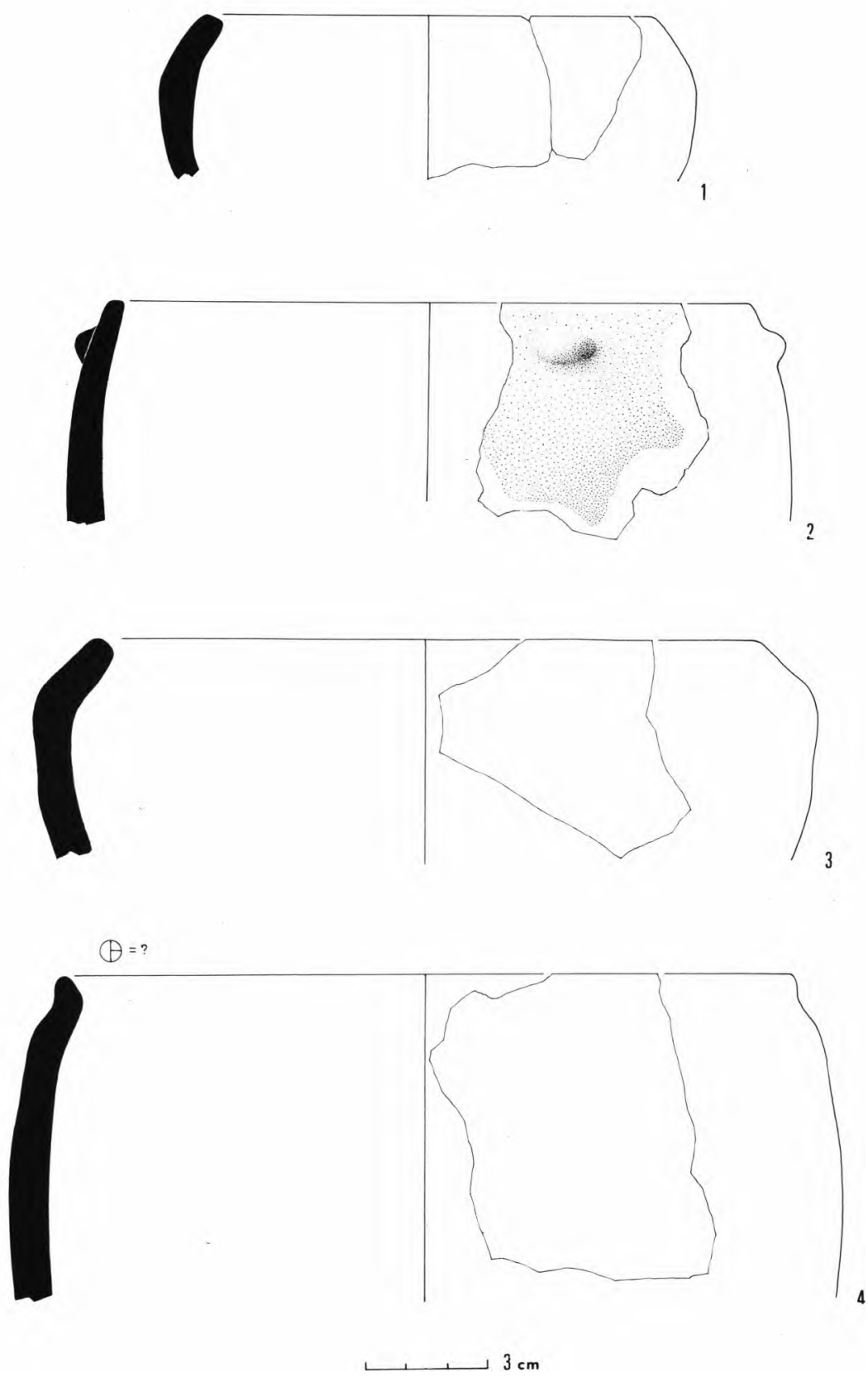
<smiles>CI</smiles> 
EST. XI
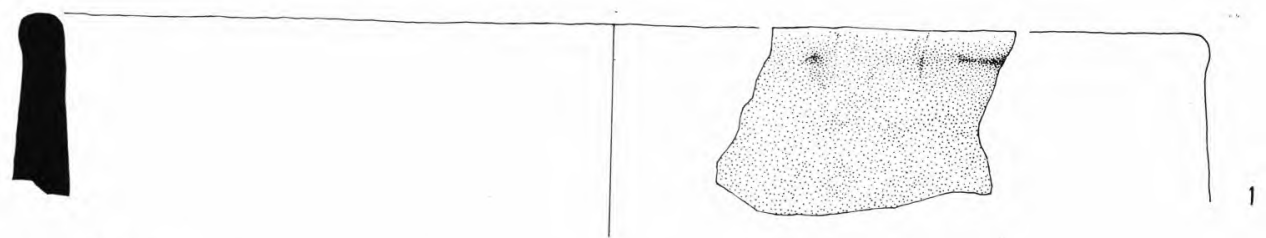

$($ A) $=24 \mathrm{~cm} \simeq$
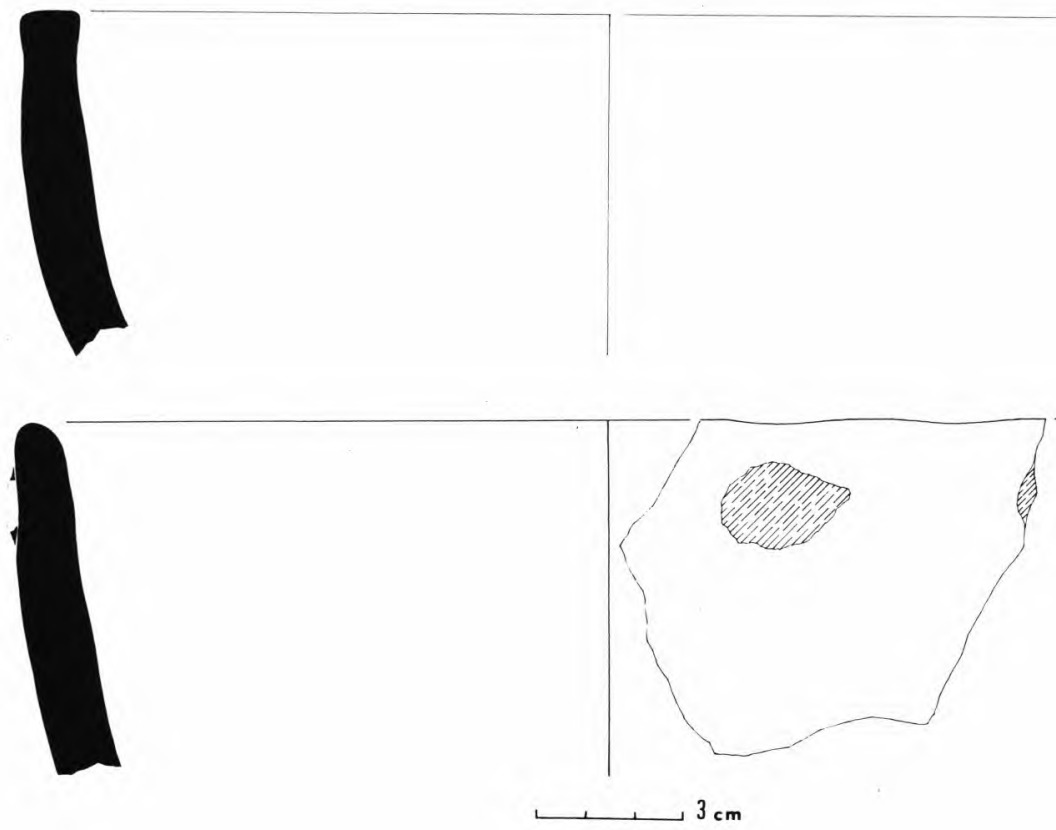
EST. XIII

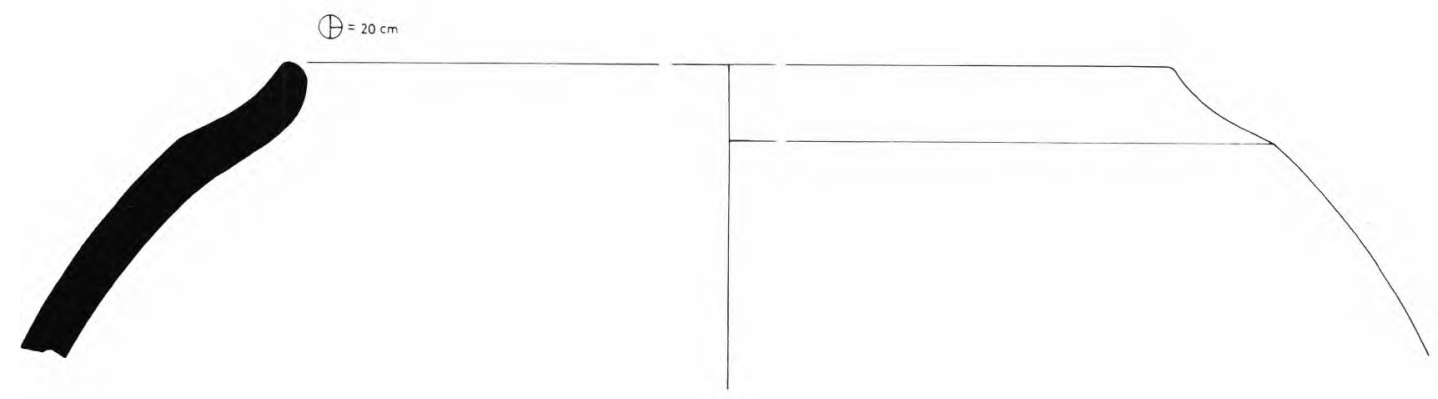

$\theta=36 \mathrm{~cm} \simeq$

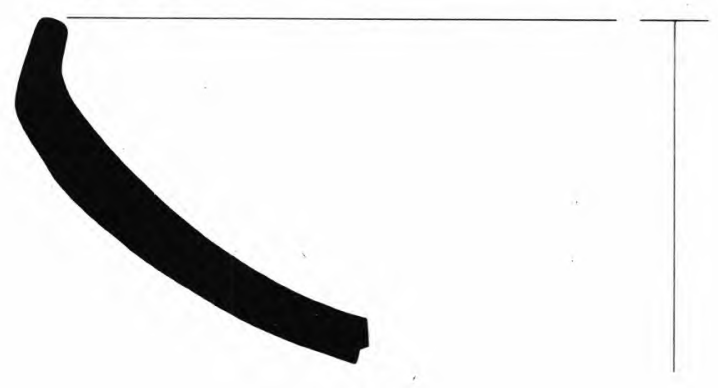

$+\quad, \quad 3 \mathrm{~cm}$ 
EsT. XIV

$\theta=$ ?

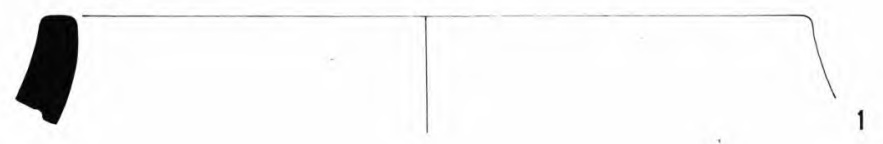

(1) =?
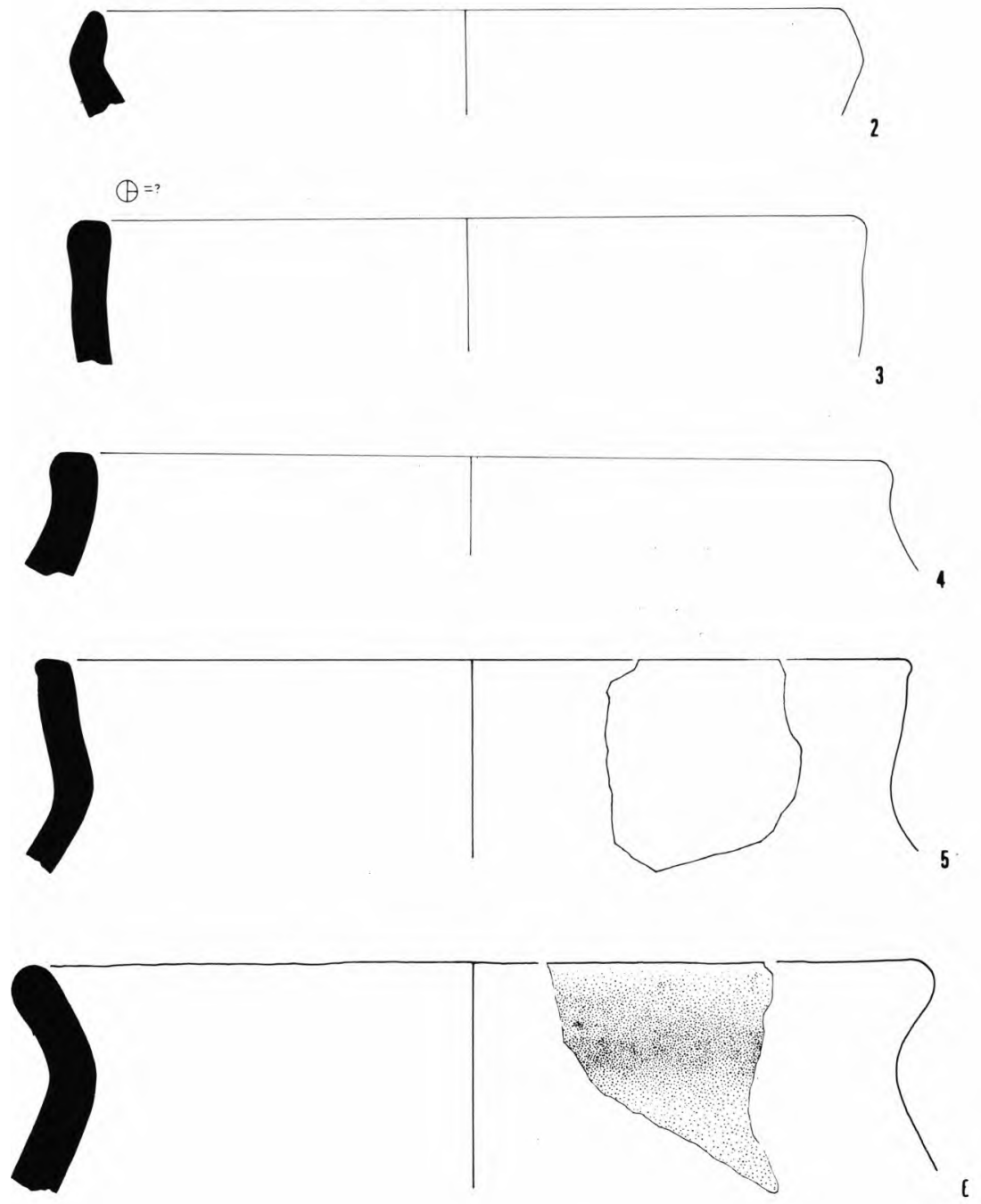


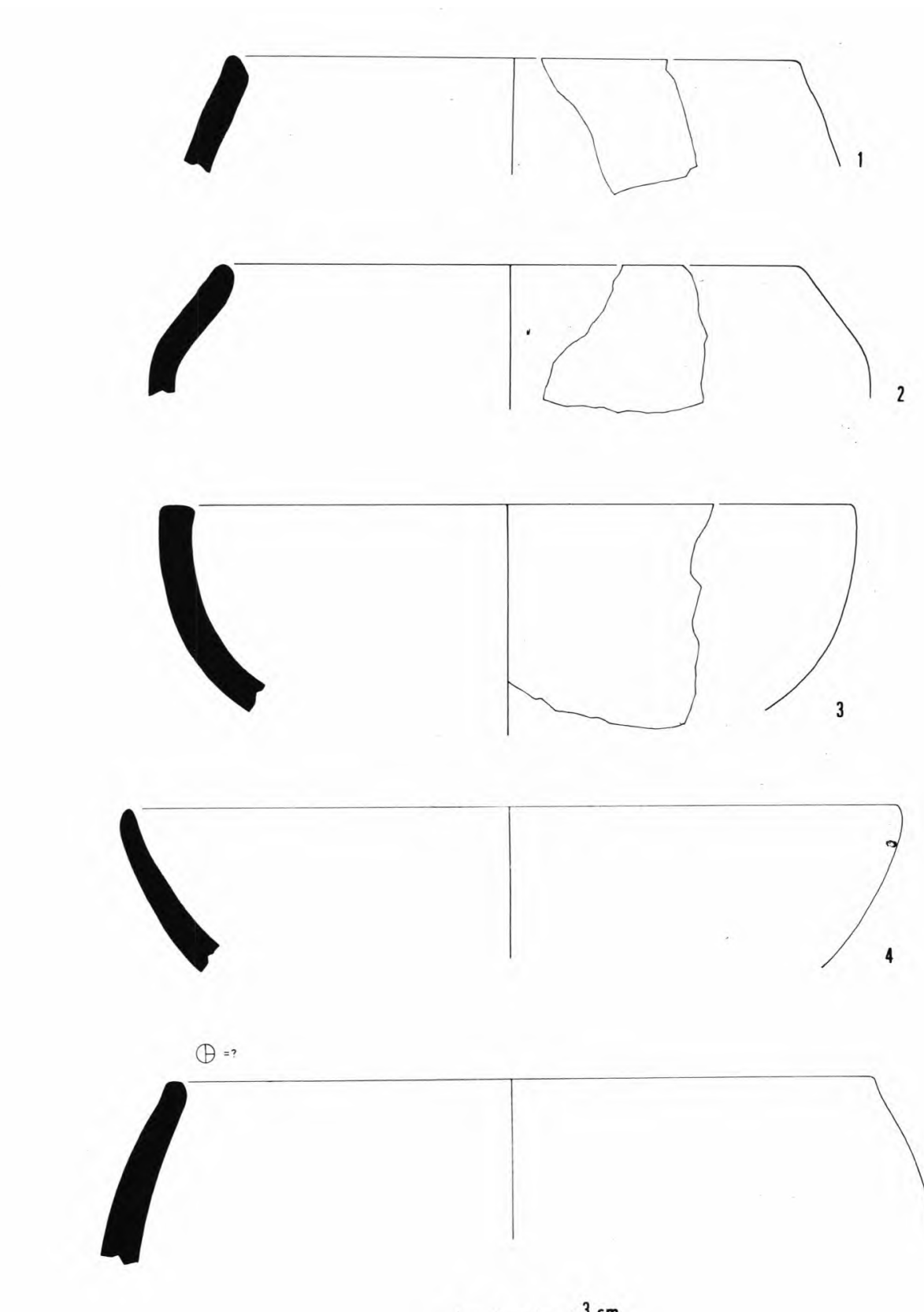


EST. XVI

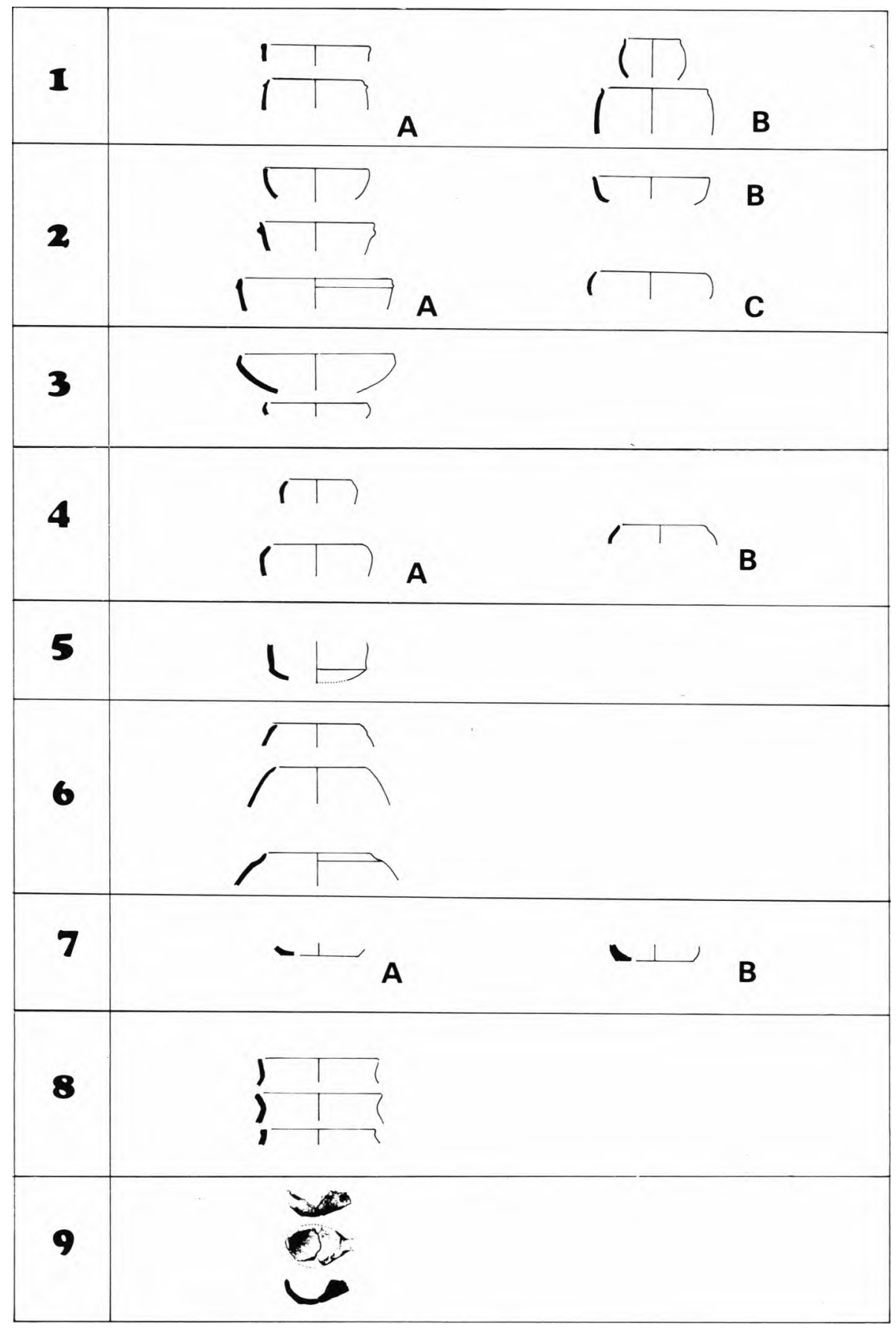


EST. XVII
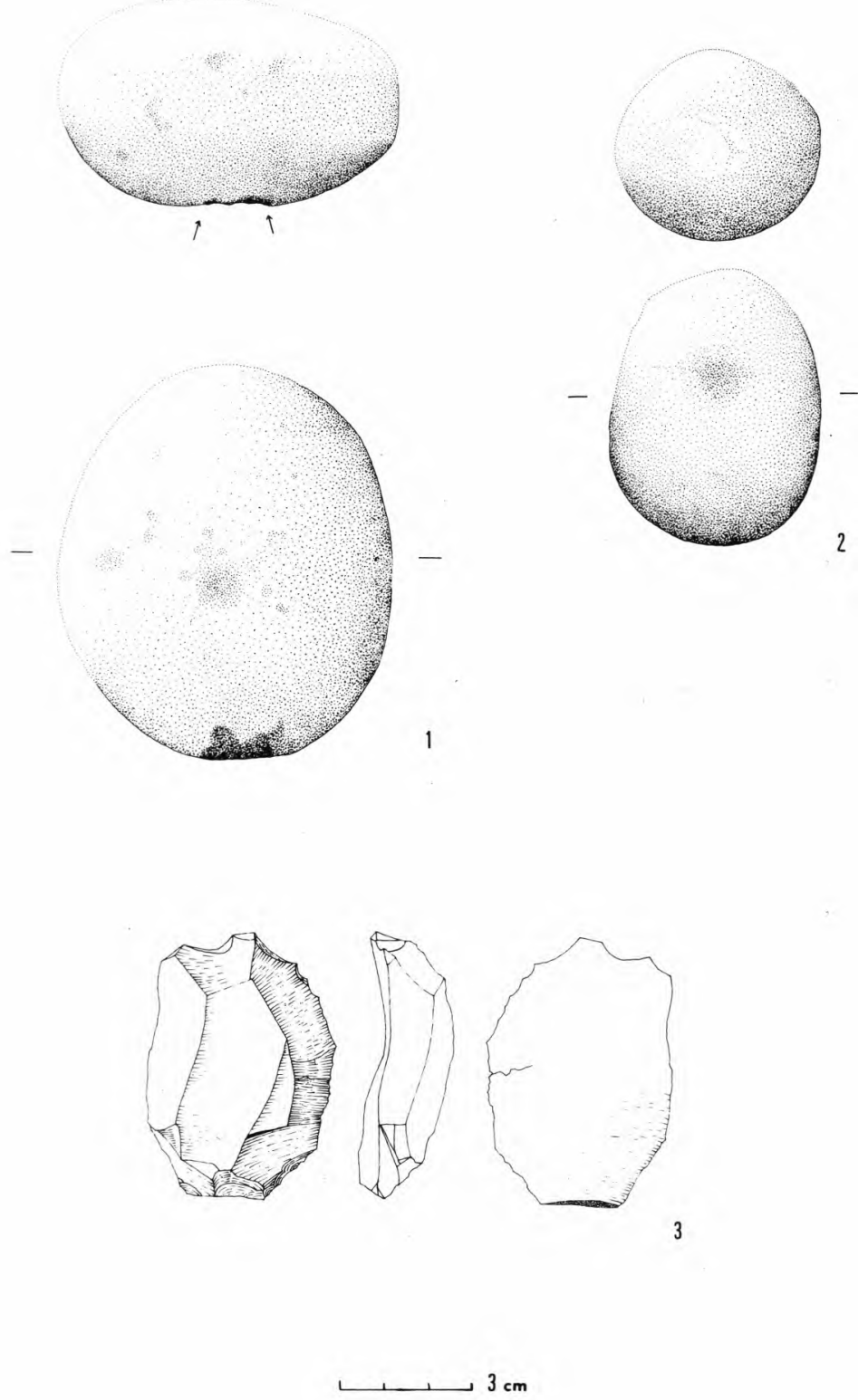
EsT. XVIII
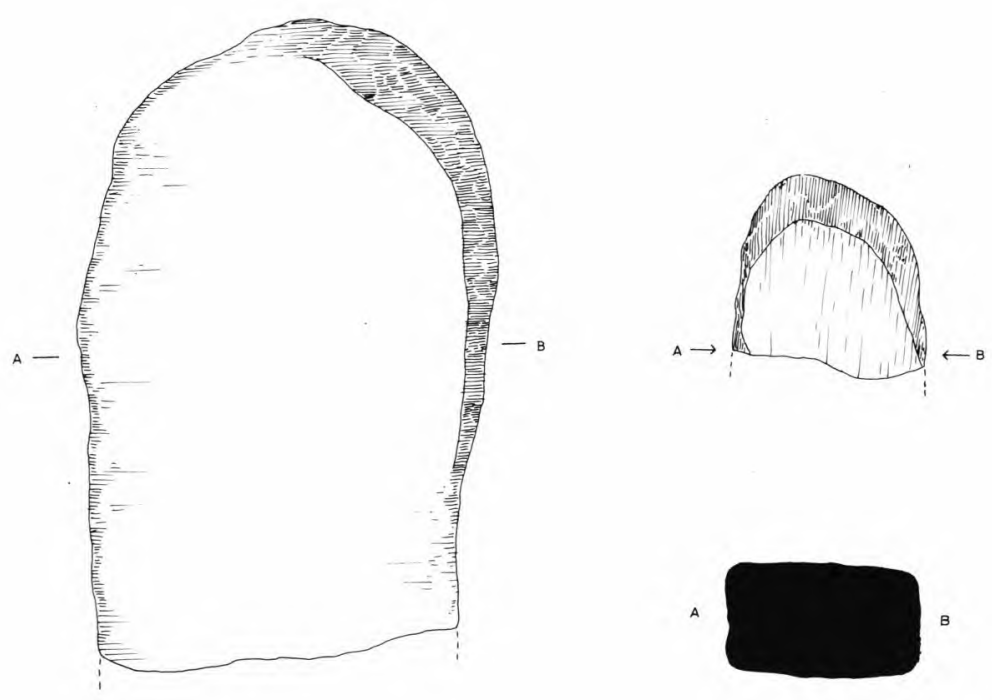

2 $10 \mathrm{~cm}$
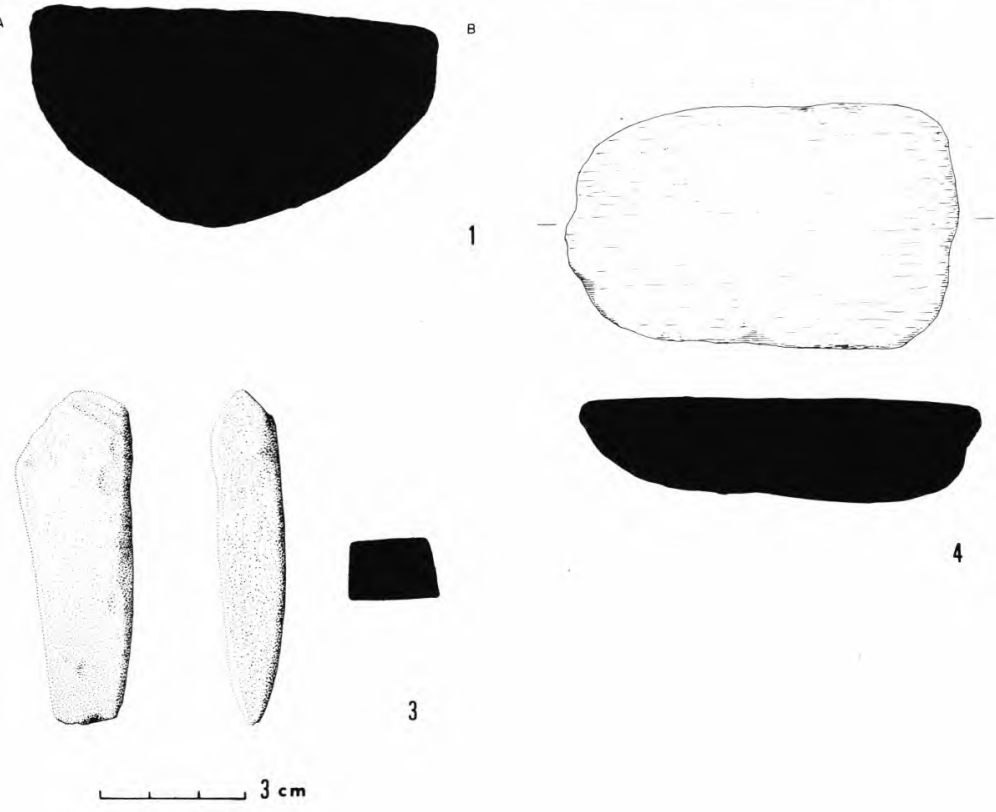
Est. XIX
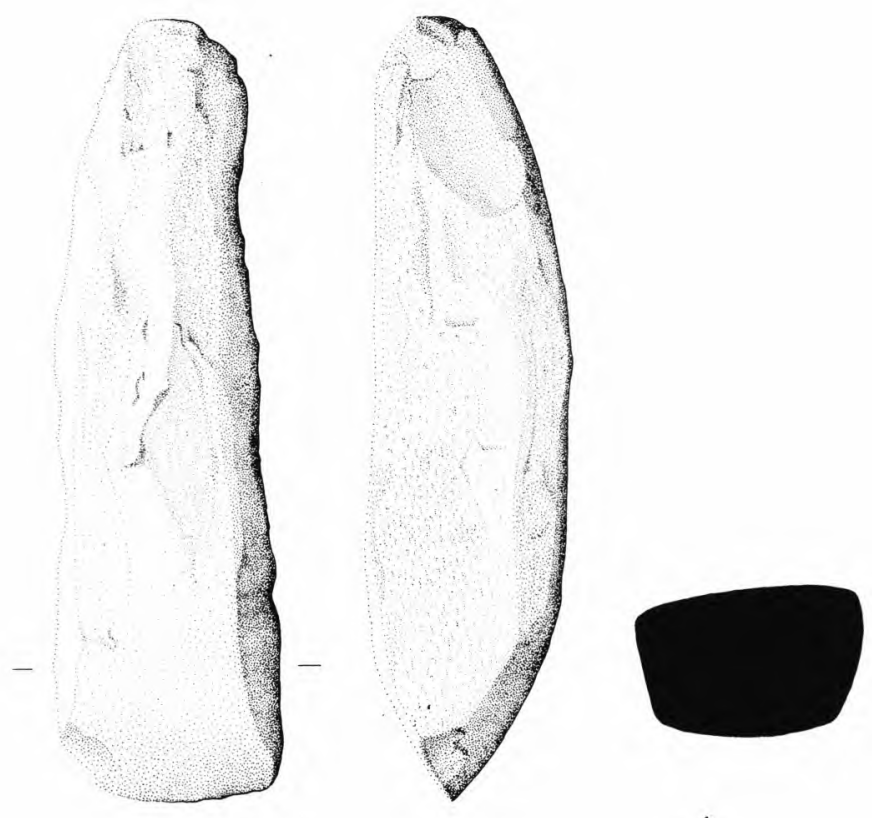

1
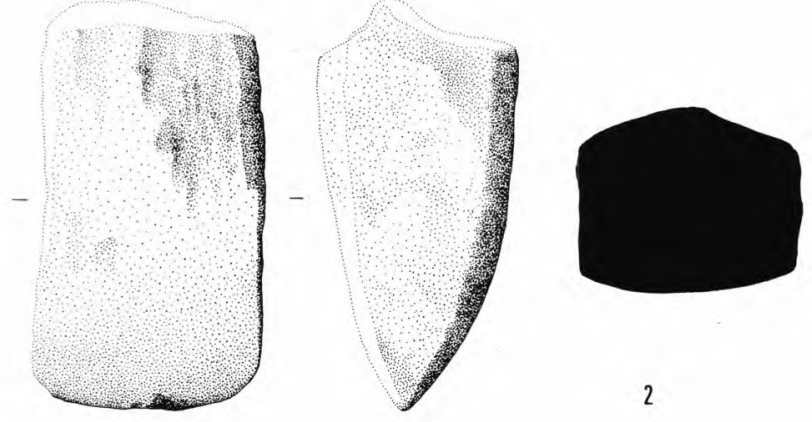

$$
3 \mathrm{~cm}
$$


EsT. XX
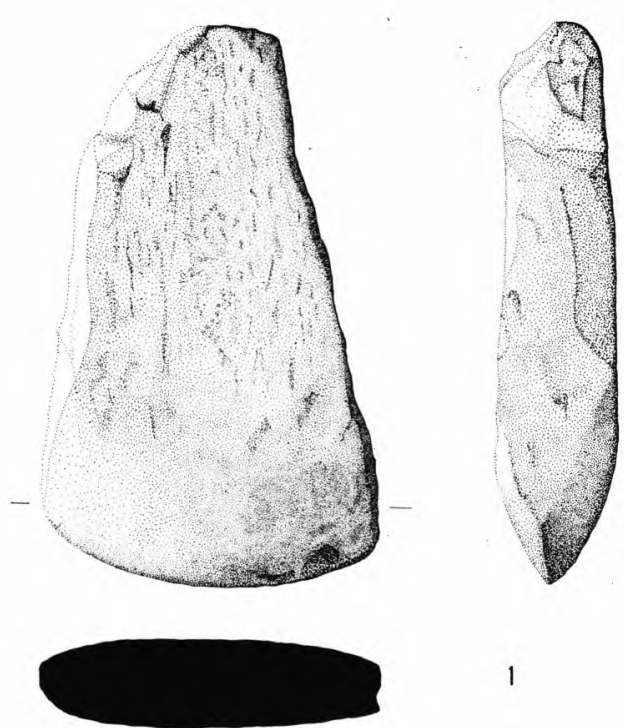

\section{1}
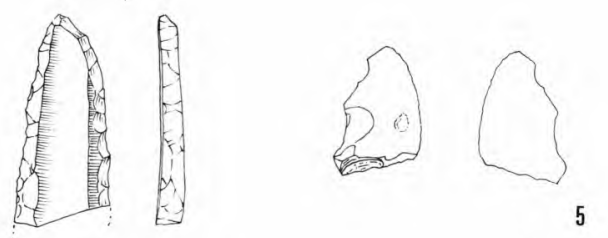

4

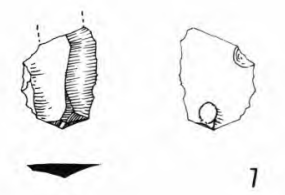

()

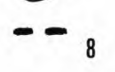

?

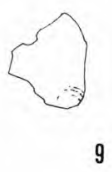




\section{EST. XXI}

\section{CERÂMICA - Percentagens totais}

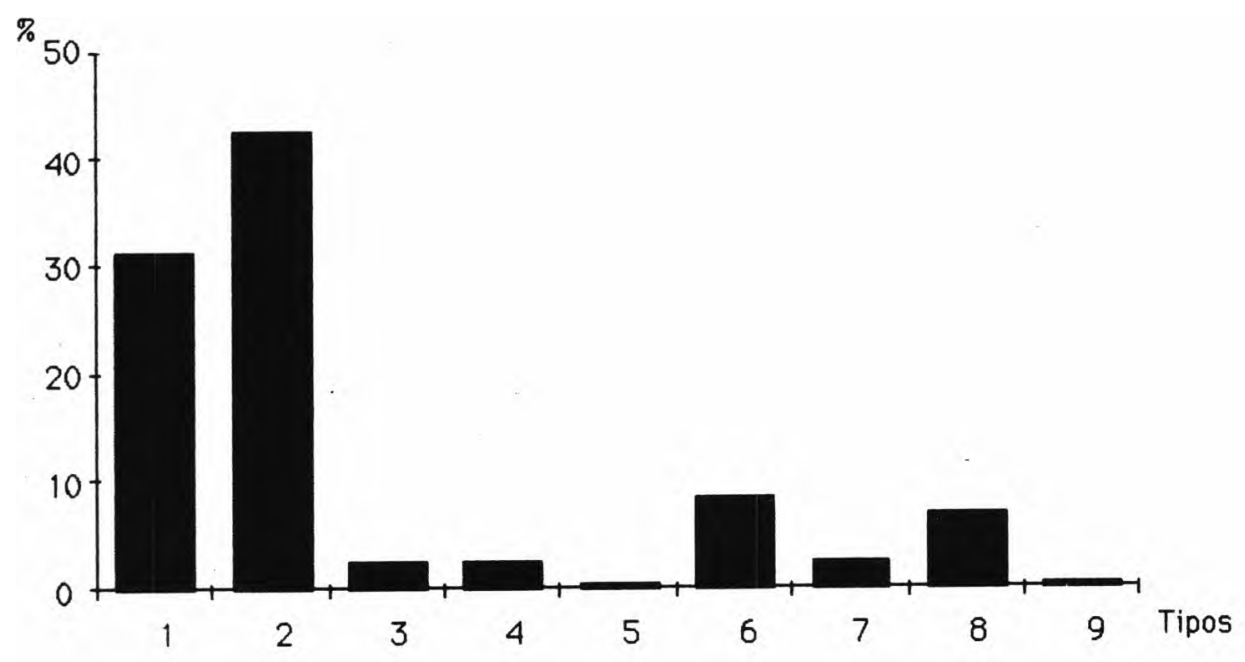




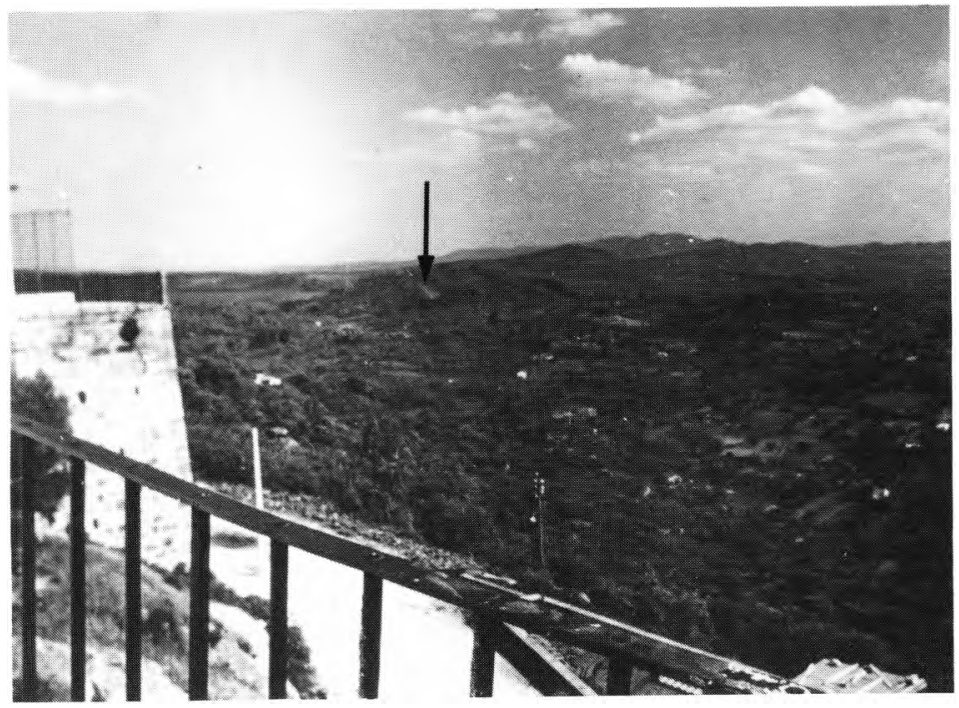

For. 1 A estação do Ramalhão vista de Noroeste (Penamacor)

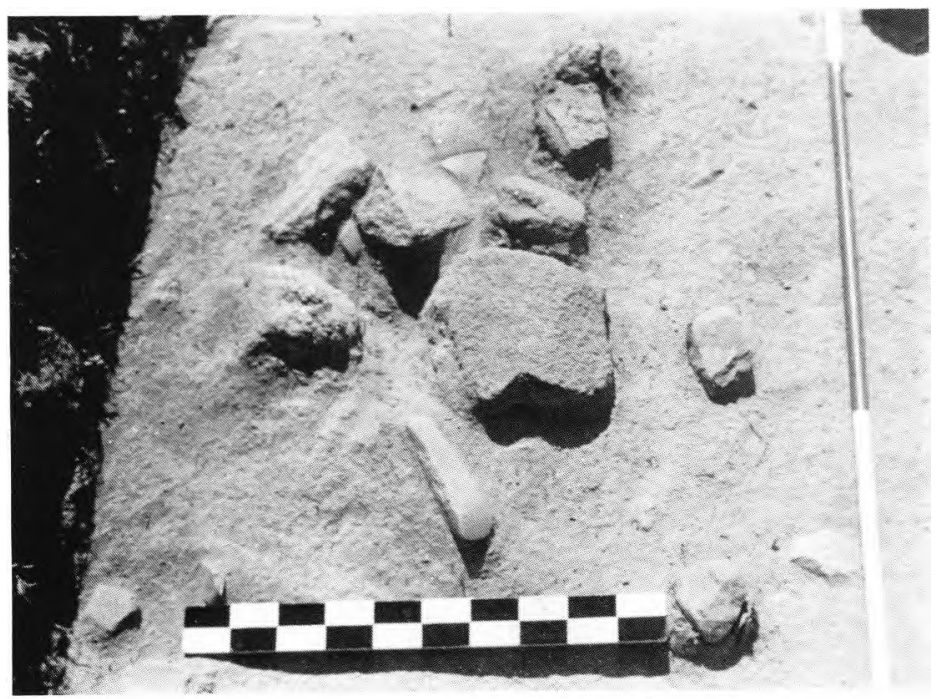

For. 2 Pormenor da escavação do sector VIII 
(Página deixada propositadamente em branco) 

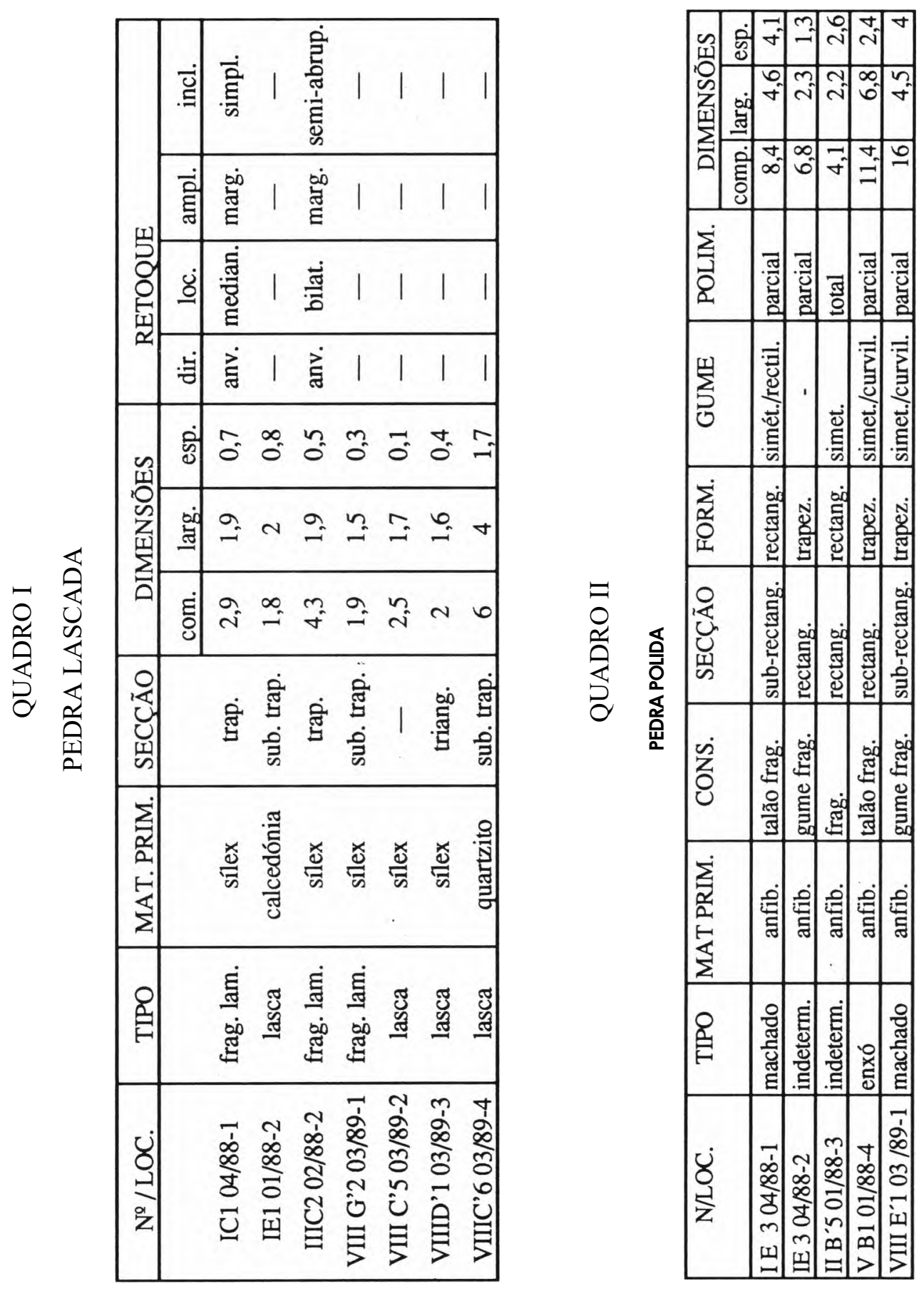

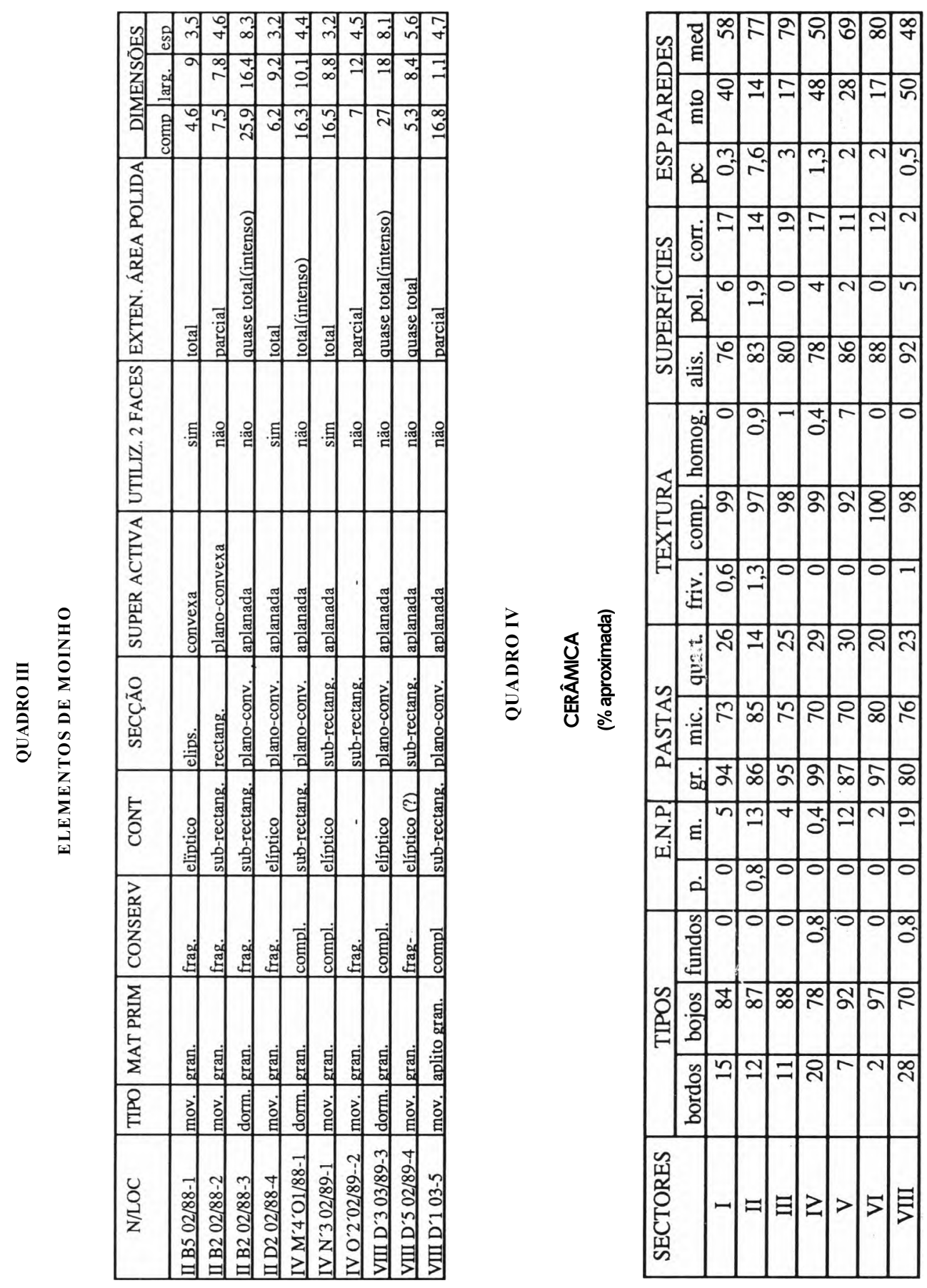